\title{
'FOREIGN BOOKS' IN ARABIC LITERATURE: DISCOURSES ON BOOKS, KNOWLEDGE AND ETHNICITY IN THE WRITINGS OF AL-ĞĀHIIZ
}

\author{
Peter Webb
}

\author{
SCHOOL OF ORIENTAL AND AFRICAN STUDIES, UNIVERSITY OF LONDON
}

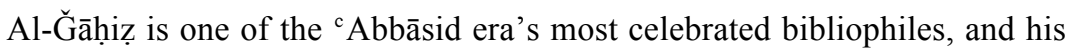
praise of books and championing of 'writerly culture' in 3rd/9th-century Iraq are well documented. However, he also expressed distinctly negative appraisals of books that have hitherto received much less scholarly attention. This paper will examine the curiously paradoxical views of alĞăhiz by considering his opinions on non-Arabic books in the context of scholarly debates in his contemporary Iraq. Al-Ğāhiz's conception of such books intersected debates regarding (a) the suitability of books to transmit knowledge, (b) rivalries between Arabs and non-Arabs in early ${ }^{\mathrm{c}}$ Abbāsid Iraq, and (c) the merits of translating scholarly writings from pre-Islamic civilisations. Al-Ğăhiz̧'s opinions on these issues led him to develop a particular conception of the 'perfect book' whereby he could unreservedly praise his own writings and extol ${ }^{\mathrm{c}} \mathrm{Abbāsid}$ literary culture, but at the same time subordinate foreign literary cultures to the non-literate pre-Islamic Arabians. Al-Ğāhizị’s theories reveal that 3rd/9th-century Iraq had not yet become entirely a 'civilisation of the book', and that conceptions of language, ethnicity and knowledge influenced the formation of Muslim bibliophilia.

In the wake of the Islamic conquests of the 1st/7th century which amalgamated the various pre-Islamic civilisations of the Near East and Mediterranean into one empire, and with the subsequent emergence of Arabic as the region's new lingua franca of cultural production, scholars in early ${ }^{\mathrm{c}} \mathrm{Abbāsid}$ Iraq (mid 2nd/8th to $3 \mathrm{rd} / 9$ th centuries) experienced an environment responding to significant social and cultural change. From the later $2 \mathrm{nd} / 8$ th century, the intellectual status quo was also confronted by technological developments which made the production of relatively inexpensive paper possible and facilitated a hitherto unprecedented opportunity for commercial book publication. ${ }^{1}$ Scholars who formerly had relied largely on the aural acquisition of knowledge via lectures now could study from a growing library of books and disseminate their research and ideas to a wider reading public. The unique advantages of books to store and transmit knowledge were apparent to 3rd/9th-century

1 See J. Bloom Paper before Print, discussed below, note 65 . 
intellectuals who praised writing specifically for this ability to communicate across time and space in ways that the oral/aural teacher/student relationship was physically unable to match. ${ }^{2}$

Akin to many such momentous epistemological and technological changes throughout history, the introduction of books and the integration of various ethnicities into the new social order of the 3rd/9th century were controversial and stimulated spirited debates which propelled Muslim civilisation along new trajectories. From the 4th/10th century, these eventually led to the bibliophilia and cultural unity for which medieval Muslim civilisation is famous. ${ }^{3}$ But in the $2 \mathrm{nd} / 8$ th and $3 \mathrm{rd} / 9$ th centuries, scholars were in the midst of debate over whether a mute, inanimate book could sensibly replace a speaking, living lecturer as an authoritative source for knowledge, while the different ethnicities of the Muslim world vigorously jostled for status. ${ }^{4}$ These discourses collided with a third intellectual challenge when Arabic-speaking scholars began to translate and reflect on the books of Greco-Roman, Sāsānid Persian, Indian and other pre-Islamic cultures.

The 'translation movement', which began in the early $2 \mathrm{nd} / 8$ th century (perhaps even before), ${ }^{5}$ made Arabic translations of pre-Islamic

2 See, for example, the praise of haț (writing) in both al-Ğāhiz's $R$. alMúcallimīn (Rasā̄il, 3: 27), and Hayawān (1: 49-52).

3 Regarding the cultural bibliophilia, S. Toorawa identifies the late 4th/10th century as a time when 'reliance on books would become pro forma' (Ibn Abi Tăhir, 24). This was the period of Ibn al-Nadīm, whose lengthy Fihrist stands as a monument to the writerly culture of his generation. The cultural unity of the medieval Islamic world is well known, neatly encapsulated by a verse Badī $^{\mathrm{c}}$ alZamān al-Hamadān̄i composed for his al-Maqāma al- ${ }^{c} i l m i y y a ~(M a q a \bar{m} a \bar{t}, 203)$ :

Alexandria is my home, Should I settle there;

But in Syria I spend the night, and in Iraq, my day.

4 Extant evidence for the controversies surrounding these debates can be adduced from bans on selling certain books in 279 and 284 reported in al-Tabarī (Tārīh, 10: 27, 54) (also discussed by S. Toorawa Ibn Abi TTāhir, 20); the heated debate over writing Islamic traditions (M. Cook 'The Opponents'); and the discordant pro-Arab/anti-Arab Šucubiyya-style polemics so commonly encountered in $3 \mathrm{rd} / 9$ th century $a d a b$ texts, including those of al-Ğāhiz. L. Behzadi's summary is apt: 'ongoing discourses of [al-Ğāhị's] time must have been much more colourful than we usually assume' (Sprache und Verstehen, 175).

5 Traditionally, the translation movement has been associated with al$\mathrm{Ma}^{\mathrm{o} m u \bar{n}}$ (r. 198/813-218/833), but more recently, scholars have identified the urge to absorb and translate foreign knowledge from an earlier date, during the caliphates of al-Manșūr (r. 136/754-158/775 and Hārūn al-Rashīd (r. 170/786193/809), and perhaps the late Umayyad period (R. Rashed, 'Greek into 
scholarly texts widespread by the early $3 \mathrm{rd} / 9$ th century. ${ }^{6}$ The translated texts differed starkly from the nascent Islamic sciences and Arabic philology, not only in terms of content, but also in form. Significantly, the translated texts were rooted in a manuscript tradition that contrasted with the Islamic and Arabic sciences where aurality was asserted as a key component of authority and authenticity. Furthermore, they were originally written in the distant past and in non-Arabic languages by peoples with neither geographical connection to Arabia, nor temporal proximity to Islamic history.

Muslim scholars in the late $2 \mathrm{nd} / 8$ th and $3 \mathrm{rd} / 9$ th centuries thus simultaneously confronted issues of integrating diverse intellectual traditions of the Near East, theorising the acceptability of books as a means of transmitting knowledge, and accommodating multiple ethnicities into their social order. I suggest that these debates were interrelated and led 3rd/9th-century writers to adopt ambivalent positions which can be seen as steps on the way towards the more defined literate, bibliophilic and culturally inquisitive outlook of subsequent centuries. On the one hand, the budding bibliophilia of the 3rd/9th century would aid the favourable reception of both Arabic books and translated 'preIslamic' manuscripts, but the tensions inherent in the process of Arabicising a multi-ethnic society thrust non-Arabic writings into debates about how the polyglot heritage of the Muslim civilisation should be navigated. This paper will explore the way in which the Iraqi polymath, "Amr ibn Baḥr al-Ğāhiz (d. 255/869) conceptualised 'the book' in the context of his views on non-Arabic peoples and the production of knowledge. Al-Ğāḥiz may not be a squarely 'typical' scholar of his time, if such a notion should indeed exist, ${ }^{7}$ but his writings on these debates are extensive and demonstrate their interrelatedness.

Arabic', 161-7; G. Saliba, 'Al-Ǧāḥiz', 41-2). The earlier beginnings of translation activity are also evidenced in the Islamic tradition: al-Fihrist of Ibn al-Nadīm (written 377/938) notes the role of al-Manșūr and al-Rashīd (Fihrist, 304-305, 333) and even suggests that the Umayyads commenced part of this venture, citing Hišām's (r. 105/724-125/743) and al-Hağğāğ's arabising of public records and translating some ${ }^{c}$ ilm (knowledge) into Arabic (Fihrist, 303).

6 'Foreign books' commonly encountered in 3rd/9th century Arabic literature are Greek mathematical, scientific and philosophical writings, Sāsānid Persian historical and legendary court literature and collected aphorisms of a devotional and philosophical nature from Sāsānid Persia and India.

7 S. Toorawa criticises the trend in modern scholarship to identify al-Ğāhị with the ethos of the 3rd/9th century (Ibn Abi TTähir, 124-7), however, I believe it may be difficult to ascribe to anyone the attributes of a 'standard' citizen of 
Al-Ǧāhịiz was a prolific writer ${ }^{8}$ and avid reader, identified in both medieval and modern writings as one of Islam's most famous bibliophiles. ${ }^{9}$ Some later biographers even reported that books caused his death, crushing him around his ninety-fifth year under a collapsed bookcase! ${ }^{10}$ But in contrast to reports of his bibliophilia, al-Ğāhiz himself expressed ambivalent opinions on the utility of books. On the one hand, his well-known love of knowledge seems to have engendered his respect for books as vital carriers of knowledge and led him to adopt a markedly bibliocentric view of the world, whereby he appraised foreign peoples in correlation with their book production. This facet of al-Ǧāḥiz has been often cited in modern scholarship, ${ }^{11}$ but little attention has been given to a paradoxically contrary trend in his writings where he expressed doubts about books as symbols of knowledge and societal achievement, and even disparaged books and 'foreign book-producing' peoples. Resolving the contradiction of al-Ğāhiz's ambivalent

his time: how would we go about defining one of these for the 20th century? AlĞāhiz expressed views which were accepted by his patrons and contemporaries, and, as such, represents an entirely valid, while certainly not the only valid, point of reference in our understanding of this period.

8 According to Ch. Pellat, ('Nouvel essai', 119), he wrote 245 works. Many are better described as epistles, running some dozens of pages or less, though others are firmly 'books' in the 'modern' sense (G. Schoeler, 'Writing for a Reading Public', 52-3, 62-3): stand-alone texts with a set structure, and two in particular, al-Hayawān and al-Bayān wa-l-tabȳ̄n have survived in multi-volume works.

9 Yāqūt relates the statement of Abū Hiffān: 'I have neither seen nor heard of anyone who loves books and the fields of knowledge more than al-Ğāhiz' (lam ara qațtu wa-lā samictu man ahabba l-kutuba wa-l-culüma akțara mina l-Ğāhiz; Mucjam, 4: 474). See also al-Mas' ${ }^{c} \mathrm{u} d \overline{1}$ (Murūğ al-dahab, 5: 104) and Ibn alNadīm (Fihrist, 130, 208). Al-Ğăhiz's love of books is almost universally cited in modern writings about him, see Ch. Pellat 'al-Djāhiz' on his wide readings; $\mathrm{N}$. Anghelescu for his status as champion of literate culture (Langage et Culture, 63); and more generally S. Günther 'Praise to the Book!'.

10 This famous but apocryphal-sounding account of his death is reported in Ch. Pellat The Life and Works, 9. Neither al-Baġdādī's nor Yāqūt's biographies of al-Ğāḥiz mention it, recording instead that al-Ğāḥiz was in his ninety-sixth year around the time of his death and that his physical condition was extremely poor, suffering from semi-paralysis (fäliğ) and gout (niqris), and thus not likely in a fit state to browse bookshelves in his last days (al-Baghdādī, Tārīh $h, 12: 214$, Yāqūt, $M u^{c}$ jam, 4: 492, 496-8).

11 See, particularly N. Anghelescu Langage et Culture and S. Günther 'Praise to the Book!'. 
bibliophilia must take into account the developing 'writerly culture' 12 and conceptions of 'foreign peoples' in his contemporary Iraq. His writings highlight how the hallmarks of the medieval Islamic civilisation - bibliophilia, knowledge-seeking and a cosmopolitan outlook - were closely interrelated, though not definitively conceptualised, during the first ${ }^{\mathrm{c}} \mathrm{Abbāsid}$ century.

Interpreting al-Ǧāhiz on ethnicity: a scholarly advisory

Akin to other volatile substances, analysis of al-Ğāhiz must come with appropriate caveats. He has been described as sarcastic, witty, rambling, emotive, unsystematic and elusive, more lyrical than meticulous, ${ }^{13}$ neatly summarised by one modern scholar: "who is to say what [alĞāhịz's] true intentions are - perhaps not even [al-Ğāḥiz] himself' ${ }^{14}$ AlĞāhiz makes strong arguments, though his opinions can appear to shift from one text to the next, leading readers to question whether he possessed strong opinions at all, or whether his ambivalence is a mixture of his own confusion and/or scholarly interest in debating multiple, and conflicting angles of an argument. As such, al-Ğāhiz's work does not lend itself to macrosynthesis of anecdotes from his vast oeuvre. Rather, each quotation demands microanalysis to infer its meaning in the context of the text in which it is contained. ${ }^{15}$ Despite these difficulties, I concur with some modern opinions that al-Ğāhiz may be more systematic than traditional Western research has assumed. ${ }^{16}$ Nonetheless, the complications of al-Ğāhịiz are manifold and evident in his discussions of books and ethnic groups which are the focus of this paper. As for peoples of the world, in some cases we find al-Ğāhiz praising the merits of a people, while in a different text he sharply lampoons them. ${ }^{17}$ Political

12 An appropriate term for the increasingly textual, book based approach to scholarly activity coined by S. Toorawa, Ibn Abi Tăhir (1) to describe the $a d a b$ culture of the $3 \mathrm{rd} / 9$ th and succeeding centuries.

13 See S. S. Agha, 'Language as a Component of Identity', 70-3, 80. See also S. Enderwitz, 'Culture History and Religion', 229.

14 An opinion expressed by J. Lassner, The Shaping, 121.

15 This approach to al-Ğāhị was proposed by S.S. Agha ('Language as a Component of Identity', 72-3) and is mirrored in J. Montgomery's three-fold strategy to extrapolating meaning from a given Ğāhizian text ('Speech and Nature. Part 3', 114-15).

16 J. Montgomery, borrowing from Isaiah Berlin, alludes to al-Ǧāḥiz’s 'despotic [intellectual] system' ('Speech and Nature. Part 3', 114), and Behzadi considers al-Ğāhị a 'systematic' thinker (Sprache und Verstehen, 173).

17 For example, in al-Bayān wa-l-tabyīn al-Ğāhiz denigrated the Zanj (a term particularly used to describe East Africans who arrived in al-Ǧāhịiz's Iraq as 
agendas and patronly tastes may have coloured al-Ğāhịị's analysis in particular epistles; ${ }^{18}$ and we ought to exercise further caution in interpreting his texts at face value, for, in addition to the sarcasm and tongue-in-cheek sometimes apparent in his style, al-Ǧāhiz wrote in polemical genres which fostered exaggeration and embellishment at the expense of sober discourse.

It has been noted that al-Ğāhiz was singularly influenced by discourses emanating from the genre al-Maḥāsin wa-l-Masāwi (good versus bad traits) which used dialectic as a means of analysis whereby everything is imagined to be relative and all ideas could be called into question. ${ }^{19}$ Gériès has suggested how al-Ğāhiz used this methodology to good effect in his theological writings ${ }^{20}$ and it appears that al-Ğāhiz may have engaged in a similar logic regarding ethnicities. He is known to have written several contradictory pieces about peoples of the world: consider for instance a (now lost) work in praise of the South Arabian Qahtān tribal group ${ }^{21}$, and an antithetical text praising the specific merits of their rivals, the North Arabian ${ }^{\mathrm{c}}$ Adnān over Qaḥtān. ${ }^{22}$ Al-Ğāhịị’s

slaves) as 'disorganised rabble' (Bayān, 1: 137) and belittled their condition visà-vis other peoples (Bayān, 1: 384). In a separate, polemical essay entitled Fahr al-sūdān 'alā l-bị̄̂an, however, he argued their merits, describing the Zanj in entirely positive terms ( $\operatorname{Ras} \bar{a}^{\supset} i l, 1: 173-226$, particularly 195-9).

18 Noted by J. Lassner regarding Manāqib al-Turk (Virtues of the Turks) which al-Ğāhiz dedicated to the powerful Turkic wazìr al-Fath ibn Hāaān (Ras $\bar{a}^{\supset} i l, 3$ : 163; J. Lassner, The Shaping, 119-120); and Pellat proposed that alĞāhiz's al-Radd calā al-nașārāa (Rebuttal against Christians) was written for the Caliph al-Mutawakkil during a period of official anti-Christian sentiment (Le Milieu Baṣrien, 231).

19 I. Gériès, 'al-Maḥāsin wa- ${ }^{`} 1-M a s a ̄ w \overline{1}, ' E I^{2}$, v, 1223-4.

20 Ibid.

21 In 3rd/9th-century Arabic writings, Qahțān was identified as the legendary ancestor of all Southern Arabians (tribes who claimed a Yemeni origin). A rivalry between 'Northern' and 'Southern' Arabs fueled polemical treatises which tend towards a binary division of Arab tribes into these two groups. Qahțān and ${ }^{\mathrm{c}}$ Adnān became virtual by-words for these two-halves of the Arab people.

22 Rasă $\bar{a}^{\circ} l, 1: 225$. See also his Fahr al-südān which defends the merits of alSüdān (lit. 'the blacks' from sub-Saharan Africa), but also contains a condescending approach and reserved praise: for example he concedes that African slaves in Iraq lack intelligence, but ascribes this to their status as slaves and their origin from a part of Africa where people are 'devoid of beauty and sagacity (jamāl wa- $\left.{ }^{c} u q \bar{u} l\right)$. Al-Ğāhị 'promises' that in other parts of Africa, beautiful and more cultured peoples (jamāl wa-kamāl) could be found (Rasă $\bar{a}^{\mathrm{i}} \mathrm{l}$, 
ambivalence may thus represent his method for achieving a deeper understanding of his subject matter.

Notwithstanding the twists and turns of al-Ğāhiz's views on ethnicity, Lassner made an important observation regarding al-Ğāhị's epistle Manāqib al-Turk (Virtues of the Turks). He ventured that a search for compatibility between the disparate elements of ${ }^{\mathrm{c}}$ Abbāsid society lay at the root of al-Ğāhiz's writings on foreigners whereby al-Ğāhiz attempted to devise an integrating model in which non-Arabs, including al-Ğāhiz himself, could find a place in the social order. ${ }^{23}$ The desire to formulate an integrating model certainly accords well with the trend in ${ }^{c} \mathrm{Abba} s i d$ civilisation towards constructing a less divided social order. But the issue is more complex: as Pellat noted, al-Ğāhiz considered himself 'very much a member of the Arab community' and a 'passionate defender of the Arab heritage'. ${ }^{24}$ Hence, al-Ğāhiz's interest in merging various ethnicities into one social order, or perhaps a 'cultural order' unified by $a d a b$, conflicted with an Arabian particularism in his writings. As discussed above, issues of ethnicity, knowledge extracted from nonArabic sources and the authoritativeness of books were being debated simultaneously in al-Ğāḥiz's Iraq and al-Ğāḥiẓ's conflicting leanings regarding different peoples of the world interact closely with his paradoxical opinion of books.

'Foreigners' and 'foreign books' in al-Ǧăhiz's writings

In the shadow of the burgeoning translation movement in 3rd/9thcentury Iraq, the interplay of books and ethnicity in al-Ğāhiziz's thought coalesce in his writings about 'foreigners'. His conceptions of ethnicity and the relationship between 'peoples' of the world (whom al-Ğāhiz generally labels umam $)^{25}$ are complex and worthy of deeper study, ${ }^{26}$ but

1: 211-12).

23 J. Lassner, The Shaping, 119-23.

24 Ch. Pellat, The Life and Works, 3; idem, 'al-Djāḥiz', 387.

25 Al-Ğlhiz generally designates umma as the largest distinct grouping of a people. The basis upon which Al-Ğshị conceived ummas to be distinct is not always apparent, but his hierarchy of terminology which identifies umma as the largest group can be found in Manāqib al-Turk (Rasā $\bar{a}^{\supset}$, 3: 213). See also his usage of umma to distinguish the Kurds, Berbers, Africans, etc (Bayān, 1: 137); or to connote the constituent 'peoples' of the world generally, Bayān, 3: 12.

26 Al-Ğāhiz's opinions on ethnicity have been considered by modern scholars in varying degrees of detail. In addition to J. Lassner's study of Manāqib al-Turk, Pellat considers some of al-Ğāhiz's reactions to his multiethnic milieu (Le Milieu Bașrien, 224-234) and 'foreign literature' in 'Djāhiz et 
for our purposes, a brief outline of al-Ǧāhị's conception of his community and the 'outside world' indicates how his worldview was in part formed through a 'bibliocentric lens'.

Common to any analysis of identity and foreignness, al-Ğāhiz's actual genealogy (which may have been black African (aswad) or at least not Arabian ${ }^{27}$ ) is less of a concern than the community to which he expressed his belonging and upon which he based his conception of the 'outside world'. The answer to this is nuanced. Al-Ǧăhiz was certainly a partisan of the Arabs and took up their defence against those whom he called $\check{s} u c \bar{u} b \bar{s}$ (his contemporaries who lauded the past glories of nonArabian pre-Islamic peoples and argued for their superiority over the Arabs). ${ }^{28}$ But he usually refrained from identifying his own community as generically 'Arab'. At times, al-Ğāhịiz divides the 'Arabs' temporally and geographically into pre-Islamic ( $\check{g} \bar{a} h i l i y y \bar{u} n$ ), Islamic (islāmiyyūn), desert-dwelling (badawiyyūn) and settled (hadariyyūn). ${ }^{29}$ These distinctions separate al-Ğāhiz's generation of urban Arabic speakers in both time and space from the 'pure Arabians' (al-a $a^{c} r \bar{a} b$ al-hullas $)^{30}$ who inhabited desert spaces in pre-Islamic and early Islamic times. ${ }^{31} \mathrm{Al}-$ Ğāhiz usually identifies his contemporary community as 'us' (nahnnu), ${ }^{32}$ 'this nation' (hädihi al-umma) ${ }^{33}$ or 'our religious community' (millatuna $\bar{a}) .{ }^{34}$ In debates with $\check{s} u^{c} \bar{u} b \bar{\imath}$ s, al-Ğāhịiz does assume the position

la littérature comparé', although in the latter article Pellat does not discuss the parameters of 'foreignness', assuming that al-Ğāhiz treats the Persians, Greeks and Indians as foreign peoples. See also S. Enderwitz, 'Culture History and Religion' for al-Ğāhiz's view on foreigners and $a d a b$ culture.

27 On his non-Arabian origins, see Š. Dayf (al-Fann wa-l-Madāhibuhu, 154) and for mention of his 'aswad' roots see al-Baġdādī (Târīh Bag̀dād, 12: 209), Yāqūt $\left(\mathrm{Mu}^{\mathrm{c}} \mathrm{g} a \mathrm{~m}, 4: 473\right)$. On the other hand, ' $\mathrm{A}$. Arḥīla defends al-Ğāḥiẓ’s Arabian origins (al-Kitāb, 29).

28 Bayān wa-l-tabyīn in particular refers to these partisans of pre-Islamic, non-Arabian peoples as $a l-s^{c} u^{c} \bar{u} b i y y a$ (see $1: 383 ; 3: 5,29,31,89$ ).

29 Bayān, 1: 9.

30 Bayān, 3: 29.

31 See Bayān, 1: 384 where he uses the expression ${ }^{c}$ arab al-ğāhiliyya wa șadr al-islām to describe the first Arabs, as historically distinct, though related to those whom he calls in the same passage 'our community' (ummatunā).

32 E.g., Bayān, 3: 366, where he refers to the ${ }^{\mathrm{c}}$ Abbāsid caliphs as 'our caliphs' (hulafă $\left.\bar{a}^{\circ} u n \bar{a}\right)$.

33 Bayān, 1: 368.

34 Bayān, 1: 137. For the translation of milla, see Ibn Manzūu, Lisān (11: 631) where it is defined as $\operatorname{din} w a-\check{s}^{\prime} a r \bar{c} c a$ ('religion and religious law') and alHalīl, ${ }^{c}$ Ayn (8: 324) where it is related specifically to the communal religious 
of 'the Arab', ${ }^{35}$ but his general reticence to label his community as simply 'Arabs' is evident and logical given the diverse ethnic backgrounds in 3rd/9th century Iraq. Thus, al-Ğāḥiz’s umma could perhaps be considered Arabicised without being Arabian, ${ }^{36}$ maintaining a link to the ' $a^{c} r \bar{a} b$ ' Arabians to the extent of its preservation of their 'correct' Arabic language. ${ }^{37}$ The maintenance of 'proper Arabic' emerges in al-Ğăhiz̧'s writing as the privilege of scholars, betraying an intellectual elitism, much remarked upon in modern literature. ${ }^{38}$ In brief, this restricted his community to the educated 'reading public'39 and he expressed little regard for the uneducated, ${ }^{40}$ and even less for the group he labelled $a^{c} \bar{a} r \bar{\imath} b$ : inarticulate Arabic speakers of vile origin. ${ }^{41} \mathrm{Al}-$ Ğāhiz's 'us' accordingly connotes a narrow band of literate, educated, Arabic speakers who inhabited the urban centres of the Muslim world and share 'our religious community (milla), our religion (dinn), our language, our education/manners (adab), and our ethics (ahlāq)' ${ }^{42}$ Ties of religion, language, education and ethics appear more determinative than strict genealogy.

In terms of the rest of humanity, al-Ğāhị often presents a two-fold

law of a group of people.

${ }^{35}$ See, for example, his hypothetical dispute with the $\check{s} u^{c} \bar{u} b \bar{l}$ s where he and the Arabs are addressed collectively with the second person plural pronoun, antum (Bayan, 3: 14).

36 By the term 'Arabian' I intend the Arabic-speaking peoples who inhabit the area now identified as the Arabian Peninsula. They are to be distinguished from Arabic speakers of the urban centres of the ${ }^{\mathrm{c}} \mathrm{Abba}$ sid period. The urban Arabic speakers were also aware of this difference, commonly (although not exclusively) applying the term ${ }^{c}$ ara $\bar{b}$ to connote the desert-dwelling Arabs. To use al-Jāhiẓ's terminology, I mean by 'Arabians', al-Jāhịiz's badwaiyyūn of the pre-Islamic and Islamic periods. The 'long-standing integration' of nonArabians like al-Ğāhaiz into an Arabised identity is discussed in Ch. Pellat, Le Milieu Bașrien, which Pellat considers the cause for the non-Arabian al-Ğạhiz to side with Arabians in contemporary racial debates (53-5).

37 Bayān, 1: 145. The full text is translated below at note 147.

38 See, for example, J. Montgomery, 'Speech and Nature. Part 3', 112, 118-19.

39 Identified by Toorawa as 'landlords, landowners, merchants, entrepreneurs, judges, jurists, physicians, poets, littèratures, teachers and other scholars' (Ibn Abī Tayfür 1-2).

${ }^{40}$ For example, his definition of 'general populace' (al- ${ }^{c}$ awāmm) even explicitly excludes farmers, market sellers, tradesmen and the hishwa ('lowlifes'), Bayān, 1: 137.

${ }^{41}$ Bayān, 1: 146.

42 Bayān, 1: 137. 
division of ummas. He explicitly identified only four 'noteworthy' $(m a \underline{d} k \bar{u} r)$ peoples of the world: 'Arabs' (perhaps he means particularly Arabs from pre-Islamic up to Umayyad times ${ }^{43}$ ), Persians, Indians and the Rūm. ${ }^{44} \mathrm{He}$ cast the rest as hamağ aw mā yušbih al-hamağ ('disorganised rabble to varying degrees'). ${ }^{45}$ Al-Ǧāhịiz's restricting of praise to these four peoples mirrors his approach to his own community and demonstrates a pivotal role of the 'book' in shaping his worldview. Al-Ğāhiz explains that his appraisal of world peoples was determined on an intellectual basis, declaring the above quartet as worthy of his esteem on account of their 'manners, education, wisdom and learning'. ${ }^{46} \mathrm{He}$ further specifies the Persians, Indians and Rūm as the only peoples whom he believed had developed advanced conceptions of rhetoric (balägha), ${ }^{47}$ produced books and possessed commendable literary traditions. ${ }^{48}$

43 He notes that the Umayyads preserved the praiseworthy traditions and qualities of the pre-Islamic Arabs, whilst al-Ğāhiz remarks that these traditions suffered a decline during the 'Abbāsid period. As such, the 'Arabs' are relatively historically remote in much of al-Bayān wa-l-tabyin and many of the more excellent aspects of their culture seem, in al-Ğāhiz's view, to have passed (Bayān, 3: 366-367).

44 Bayān, 1: 137, see also Bayān, 1: 384, Hayawān, 1: 53. The term 'Rūm generally designates contemporary Byzantines in Arabic texts, but can also refer to the Greco-Roman civilization. What we refer to today as the Ancient Greek civilization is usually identified as al-Yünān. However, there is occasional overlap in Arabic writings of the 3rd/9th and 4th/10th centuries where the relationship between $R \bar{u} m$ and Yūnān were variously interpreted, sometimes alYünān were deemed as descended from al-Rüm. Al-Mas ${ }^{\mathrm{c}} \overline{\mathrm{u}} \mathrm{d} \overline{\mathrm{i}}$ helpfully summarises the various opinions and notes how the later al-R̄um lived in the same lands as al-Yūnān and adopted their language and ways (madhhab) (Murūj 2: 664). Al-Jāhiz cites al-Yūnān as a 'disappeared peoples' (umma bā'ida) (Bayān 1: 188), although in his epistle al-Radd 'alā al-Nașārā, both al-Rūm and al-Yūnān are cited, indicating a perceived continuity between these two peoples in his worldview.

45 Bayān, 1: 137, Hamağ derives from flies or gnats which cluster around sheep and donkeys (Ibn Manzūr, Lisān, 2: 393). It is applied to people by analogy on account of the diminutive size of gnats and disorganisation of their flight (ibid, al-Zamahšarī, Asās al-Balāgha, 706). Rabble or riffraff could act as translations.

46 They are described as al-umam allatī fìhā l-ahlāq wa-l-ādāb wa-l-hukm wa-l- ${ }^{c} i l m$ (Bayān, 1: 384).

47 Bayān, 1: 88 .

48 Bayān, 3: 13, Hayawān, 1: 53. 
As regards the outside world, therefore, al-Ǧăhiz adopted a distinctly bibliocentric lens by which 'foreign' book producing peoples were accepted to join the 'Arabs' in the global hierarchy, while those whom al-Ğāhiz believed lacked literary traditions were excluded. Precisely why 'the book' could be utilised as an arbiter between madhkūr (worthwhile') and hamaj ('worthless') peoples and the precise workings of this worldview in al-Ğāhiz's writings, can be understood in the context of the conceptions of books and knowledge in al-Ğāḥiz’s society.

The nexus of 'book-knowledge-civilisation' in Muslim thought Al-Ğāhiz's 'intellectual elitist' worldview indicates a profound respect for knowledge $\left({ }^{c} \mathrm{ilm}\right)$ and a conceptualisation of books (kutub) as representing physical embodiments of cilm. ${ }^{49}$ The three 'foreign' peoples, qua book producers, generated ${ }^{c} \mathrm{ilm}$ and so earned the right to exist alongside the Arabs whose ${ }^{c} i l m$ al-Ğāhiz vigorously defended in his writings. This seems to harbinger a model of 'universal bibliophilia' encountered in later medieval Arabic writing where literary output and the worth of foreign peoples are unambiguously connected. ${ }^{50}$ This bibliophilia of the medieval period has led scholars to label the Muslim world a 'civilisation of the book' 51 and the role of books in al-Ğāhiz's worldview seems to be an early expression of this 'global' aspect of Muslim bibliophilia. In seeking the origins of the Muslim partiality to books, Western scholars have traditionally considered that the prototypical respect of kitāb and ${ }^{c} i l m$ emanate directly from the Qur ${ }^{\circ} \bar{n} .^{52}$ The Qur ${ }^{\circ} \bar{n}$ does contain a literate-intellectualised conception

49 Al-Ğāḥiẓ's esteem for knowledge is famous (Ch. Pellat, Le Milieu Bașrien, 68), and al-Ğāhị's dual conception of books-knowledge has been noted by ${ }^{\mathrm{c}}$ A. Arhīla, al-Kitāb (see particularly 16, 66, 142) and N. Anghelescu, Langage et Culture, 59-59. Al-Ğāhiz wrote specifically on the topic of knowledge, composing texts entitled Faḍl al-ilm, Risālat al-mucallimīn, al${ }^{c} \bar{A} l i m$ wa-l-ğāhil and three separate texts about ma $^{c}$ rifa. Ch. Pellat, 'Nouvel essai', 130, 141, 147-8.

50 For an archetypal expression of this bibliocentrism, see Tabaqāt al-Umam of Șā $\bar{a}^{\mathrm{c}}$ id ibn Aḥmad al-Andalusī (d. 462/1070). See note [65] below.

51 G. N. Atiyeh, The Book in the Islamic World, xiv. J. Pedersen's The Arabic Book is the classic exploration of the paradigmatic 'bibliophilia' in Islam. See also J. Bloom Paper Before Print (116-23) for a description of the outpouring of 'book culture' and S. Günther's 'Praise to the Book!', 126 for the scholarly backing of this enterprise.

52 J. Pedersen opens his classic work with the phrase 'The Arabic book owes its origin to Islam' (The Arabic Book, 3) and identifies the Qur ${ }^{\circ} \bar{a} n$ as the first 'proper' Arab book (ibid., 12-16). As for 'ilm (knowledge), F. Rosenthal 
of human existence: it makes myriad citation of kitāb and ${ }^{c} i l m$, it teaches that the kitāb will 'release the people from darkness into light' (Qur'ān 14:1), and it closely equates 'ilm with the ideal human condition, describing Muslims as those who have or seek ${ }^{c} i l m$, in contrast to nonbelievers who act 'without it' (Qur'ān 31:20). ${ }^{53}$ However, the inference that the Qur ${ }^{\circ} \bar{a}$ is the basis of later expressions of Muslim intellectualised bibliophilia risks anachronism. ${ }^{54}$

While the Qur ${ }^{0} \bar{a}$, al-Ğăhiz and later Muslim writers all seem united in the same knowledge-seeking bibliophilic chorus, current scholarship is revealing that the acceptance of books as authoritative depositories of ${ }^{c} \mathrm{ilm}$ was a protracted process, the stages of which ought to be separated. First, in an insightful monograph, Madigan demonstrated that the Qur'ānic conception of the 'enlightening kitāb' was not a 'book' in the modern sense of a closed, definitive, authored text. Madigan argued that the Qur'ānic 'kitāb' is a symbol for God's authoritative knowledge, representing the totality of His guidance to mankind. It thereby transcends terrestrial, time-bound texts, ${ }^{55}$ and, in fact, the Qur ${ }^{\circ} \bar{a}$ states

considered the history and importance of ${ }^{~} i l m$ throughout Muslim thought, proposing that prior to Islam the Arabians had a very limited appreciation for ${ }^{c}$ ilm (conceived as scholarly knowledge), and were left in a somewhat 'dark age' where knowledge was restricted to desert landmarks and practical matters of survival (Knowledge Triumphant, 9-16). According to Rosenthal, the revelation of the Qur'ān, with its particular emphasis on ${ }^{c} i l m$ (ibid., 20) ushered in the advanced theoretical epistemology (ibid., 2). See also ${ }^{\mathrm{C}} \mathrm{A}$. Arhịla for the commonly held view that wide-ranging knowledge seeking is an integral aspect of Islamic belief (al-Kitâb, 19, 67).

${ }^{53}$ In the same vein, the Qur ${ }^{\top} \bar{a}$ chastises those who ignore ${ }^{c} i l m$ when it is taught/revealed to them (Qur $\left.{ }^{\circ} \bar{a} n, 2: 145 ; 13: 37\right)$.

54 Promulgators of this conception, such as Rosenthal, do note the multifaceted meaning of cilm in Muslim thought. However, Rosenthal's analysis implies the Qur'ān has retained a determinative role in shaping 'ilm's parameters (Qur $\left.{ }^{\circ} \bar{a} n, 42-5,48-90\right)$. This analysis primarily relies on texts from the later 3rd/9th century, leaving the first 250 years of Muslim intellectual history as a stasis in which the Quranic ideal seemingly was little changed.

${ }^{55}$ For D. Madigan's elucidation on the meaning of kitāb in the Qur'ān see The Qur'ān's Self Image, $52-4 ; 70-2 ; 105 ; 145$. According to Madigan, in the language of the Qur ān, a printed copy of the text should not be referred to as $k i t a \bar{b}$, and for this reason, he proposes, the term mușhaf was adopted (ibid., 3637). When the Qur ān refers to written documents it eschews the verb kataba for physical writing (ibid., 108-9) and refers to physical 'books' with words like șuhuf and qirțās (ibid., 122-3). 
that no human-authored book can approach the power of the Kitäb.56 While the Qur ${ }^{\circ} \bar{a}$ does establish a discursive framework in which kitāb and ${ }^{c} i l m$ are connected in a tremendously positive manner and the possession of kitāb symbolises 'correct guided' life, it is unlikely that the earliest Muslim audiences associated this symbolic grandeur with terrestrial kutub (understood as human authored texts or anything 'written' ${ }^{57}$ ). The elevation of terrestrial kutub to the centrepiece of later Muslim bibliophilia is a separate phenomenon achieved via the gradual maturation of the writerly culture.

Towards a 'writerly culture': the concept of the 'book' in 3rd/9th-century Iraq Muslim 'writerly culture', which began to emerge about one hundred years after the Qur'ān's revelation, would eventually champion the human-authored book and provide the necessary theoretical backdrop to use the book in appraising peoples of the world. ${ }^{58}$ But in al-Ğāhiz's day, 'writerly culture' had not entirely matured and the status of books remained debated. Until the latter $2 \mathrm{nd} / 8$ th century, scholars were primarily praised for their capacity to memorise. ${ }^{59}$ In contrast, book 'publication' was extremely limited, ${ }^{60}$ formal writing was restricted to

56 See the Qurª̄n 2: 79 for its extreme censure of the human act of claiming their writings to be like God's kitāb.

57 A definition drawn from the earliest Arabic dictionary Kitāb al- ${ }^{c}$ Ayn, which identifies kitāb as the 'verbal noun' (mașdar) of the verb kataba 'to write' (al-Halīl, Kitāb al- 'Ayn, 5: 341).

58 Madigan notes that the impetus to ascribe terrestrial written texts with $k i t a \bar{b}$ was aided by the written codification of the Qur ${ }^{\top} \bar{a}$ in a written mușhaf during the $1 \mathrm{st} / 7$ th century which began to elevate respect for the written word (The Qur ān's Self Image, 23, 47-8).

59 Anecdotes recording the lampooning of traditionists in the 2nd century who relied on written notes and praising those who allegedly knew all their material from memory are frequently cited in debates about the authenticity of the hadi $\underline{t}$, the permissibility of writing them and the development of a written hadi $\underline{t}$ tradition. Conversely, Schoeler stresses the important role of notebooks (hypomnemata) from early times (The Oral and the Written, 114-128). Irrespective of the private use of such notes, the public display of knowledge from memory was important, witnessed by the scale of anecdote in the Islamic tradition.

60 Both Nabia Abbot (Studies in Arabic Literary Papyri) and Fuat Sezgin (Geschichte des arabischen Schrifttums, 1) gathered evidence for scholarly writings in the latter first and second centuries of Islam. Subsequent research has cast doubt on these attempts to identify primordially early texts in the Islamic tradition (G. Schoeler, The Oral and the Written, 40). 
bureaucratic matters and scholarly writing was limited to informal notebooks for personal use or shared between students. These writings, sometimes identified in the sources as kutub, should not be construed as 'books' in the sense of formally published closed-ended texts. ${ }^{61}$ Knowledge transmission was likely aided by written notes, and scholars did not only rely on their powers of memory. However, presumptions of 20th-century scholars in the tradition of Goldziher who sought to prove that the transmission of knowledge relied on writing have ignored the staunch opposition to writing as detailed by Cook and they lack evidence given the limited numbers of surviving papyri and other writing fragments from the period. ${ }^{62}$ The word of the scholar possessed greater value than his writings, ${ }^{63}$ and the authority of human written texts seems to have been somewhat mistrusted across the Islamic world, and particularly in al-Ǧāhịiz's hometown of al-Bașra. ${ }^{64}$ In this environment, the first translations of the 'foreign' texts from the Sāsānid Persian, Greek, and Indian traditions would have circulated primarily in the palaces and administrative centres and not ventured far into the circles of the wider Muslim scholarly community. ${ }^{65}$ Overall, recourse to written notes was largely outside of public view, ${ }^{66}$ books lacked authority as standalone repositories of knowledge and consequently there was therefore almost no scope in the first two centuries of Islam to accept either the notebook kutub or translations of non-Arabic texts as epitomes of authoritative knowledge transmission.

As noted above, the introduction of paper and perhaps a greater familiarity with the textual traditions of pre-Islamic Near Eastern

61 This theory was first proposed in the 19th century by Alois Sprenger and has been carefully developed in The Oral and the Written and The Genesis of Literature by Schoeler who identifies these writings as 'notebooks' / hypomnema. For a summary of the difference between hypomnema and syngramma (the published book) see G. Schoeler, The Genesis of Literature, 21.

62 M. Cook, 'The Opponents', 440.

63 Schoeler argues for a fairly wide use of the hypomnema (The Oral and the Written, 40-41). Similarly Abbott (Studies in Arabic Literary Papyri) provides ample physical evidence for the writing heritage of the Umayyads, however neither gives an indication that books were upheld as praiseworthy repositories of ${ }^{c} i l m$ - this appears to have been the characteristic of the scholar, not his books.

64 M. Cook, 'The Opponents', 444-6.

65 C.E. Bosworth, 'The Persian Impact on Arabic Literature' and G. Schoeler, The Genesis of Literature.

66 Ibid., 27. 
cultures via the growing translation movement nudged the writerly culture forwards in the latter $2 \mathrm{nd} / 8$ th century. ${ }^{67}$ At this time Sibawayh (d. 180/796) 'published' al-Kitāb: one of the very first Arabic books definitively produced by its author and released to the public in written form. ${ }^{68}$ Following Sībawayh's model, books began, slowly and rather falteringly at first, to be 'published' to a growing reading public, ${ }^{69}$ and during the lifetime of al-Ğāhiz, the book was beginning to establish itself as a definitive repository of knowledge that could be read on its own. ${ }^{70}$ With the human-authored text finally familiar and widespread in society, Muslim writerly culture could begin to conceptualise the humanauthored book as synonymous with ${ }^{c}$ ilm and right-guided living in their vein of the Qur ānic kitāb. ${ }^{71}$ As tangible objects, they became closely associated with their authors ${ }^{72}$ and as abstract symbols of knowledge,

67 The role of translated materials is discussed by ${ }^{\mathrm{c}} \mathrm{A}$. Arhịila, al-Kitāb 66-7 and the effects of increased paper production by J. Bloom, Paper Before Print, 91, 110-13. Other factors cited for the growing importance of books include the rise of administrative writings (S. Toorawa, Ibn Abi Tāahir, 1-2, 9), a gradual development from increasing reliance on the scholarly notebooks (G. Schoeler, The Genesis of Literature), the role of the $\mathrm{Mu}^{\mathrm{c}}$ tazilite sect's preference of reasoned thought over memorised facts (S. Günther, 'Praise to the Book!', 131) and a broadening of the literate public who sought books outside of a formally professional context (S. Toorawa, Ibn Abi Tāahir, 1). It would seem logical that all of the above played a part.

68 G. Schoeler, The Genesis of Literature, 88-9 who identifies this book as a syngramma - akin to the modern concept of an authored, published 'book'.

69 Schoeler cites the written poetry anthology of al-Mufaḍal al-Dabbī and Ibn Ishạa's al-Kitāb al-Kabīr as examples (The Oral and the Written, 71). Abbott compiles a list of the surviving 'books' produced in the 3rd/9th century, indicating the growing frequency of formal publication ("A Ninth-Century Fragment', 147-9).

70 Noted by S. Günther, 'Praise to the Book!' 139-140, who cites the earlier article of A. Ghersetti for evidence of the third-century opinion of the book as primary means of preserving knowledge ('L'utilità della scrittura e la lode del libro' [The Usefulness of Writing and Praise of the Book]).

71 Al-Ğāhiz explicitly makes this connection, to be considered below.

72 The close association of authors and their books begins to appear in the $3 \mathrm{rd} / 9$ th century and is even more apparent the succeeding period. The early identification of books with their authors can be noted with Mālik ibn Anas and al-Muwatt ${ }^{\supset}$, al-Buhārī and Muslim with their hadīt collections, and in the 4th/10th century we note Abū al-Farağ al-Ișfahān̄ became popularly identified

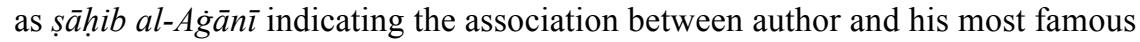
work. In a similar vein, nations would similarly become identified by their 
they became a readily deployable means to recognise cultured life. The possession of books therefore was directly linked to praiseworthy social status, opening the door for the application of a bibliophilic model to appraise other societies and past civilisations.

The writerly culture's maturation in the 3rd/9th century accords well with al-Ğăhiz's bibliophilic worldview, and the contrast with the seemingly retrenched orality of the earlier period has understandably led modern researchers to identify the $3 \mathrm{rd} / 9$ th century as literate, ${ }^{73}$ and writers such as al-Ğāhiz and Ibn Qutayba as veritable champions of the writerly culture. ${ }^{74}$ The enthusiastic appraisal of this period's literacy, however, ought to be tempered: writerly culture and the lofty status of $k i t a \bar{b}$ were in a formative stage during al-Ğāhịị's lifetime. Authors still relied on aural sources, even into the 4 th/10th century, ${ }^{75}$ and the degree of autodidactism (from books), anecdotally noted in the 3rd/9th century does not appear to have entirely superseded aural study. ${ }^{76}$ Genres such

books, and expressions such as qālat al-Rūm ('the Rüm say') or fì kutub al-Rüm ('in the books of the Rūm') are noted in texts of Ibn Qutayba (G. Lecomte, Ibn Qutayba, 190). The notion of authors acquiring a proprietary right in their book is a vast and under-explored ramification of the development of the writerly culture, however, its origins in the $3 \mathrm{rd} / 9$ th century along with the development of the critique of plagiarism are introduced in S. Toorawa, Ibn Abi Tāahir, 26-9).

${ }^{73}$ In the case of the Islamic sciences, see M. Cook ('The Opponents', 476), and more generally, S. Günther 'Praise to the Book!', and A. Ghersetti 'L'utilità della scrittura'.

74 See for example, S. Günther, who comments on the 'vigorous stance' of Ibn Qutayba and al-Ǧăhị in promoting 'reading, writing and books' ('Praise to the Book!', 138); 'A. Arḥ̄ila, who identifies al-Ǧăhiz as Islam's most renowned 'bookman' (ašhar man ahabba al-kutub) (al-Kitāb, 15); N. Anghelescu, who describes al-Ğāhiz's era as 'temps d'ouverture intellectuelle' where intellectuals paid the book great reverence (Langage et Culture, 56-8); and G. Schoeler, who argues for a much wider readership of al-Ğāhiz compared to writers of previous generations ('Writing for a Reading Public', 59-60).

${ }^{75}$ This is the topic of W. Werkmeister's research Quellenuntersuchungen zum Kitāb al- ${ }^{c}$ Iqd al-farīd des andalusiers Ibn ${ }^{~}$ Abdrabbih (246/860-328/940): ein Beitrag zur arabischen Literaturgeschichte (Berlin: Klaus Schwarz Verlag,

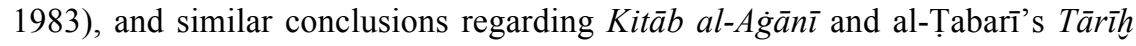
are noted in G. Schoeler, The Oral and the Written, 37-9.

76 The emergence of the autodidactic basis for self-study from books is noted by S. Toorawa, Ibn Abī Tāhir, 15-16). While this clearly formed the basis for much of the intellectual activity of the period, in the 3rd/9th century, Schoeler's evidence suggests that the autodidactic process and wiğăda ('finding' information in books) still lacked the authority of learning from formal lessons 
as philosophy and medicine may have been less fettered by oral legacies, but this should not distract us from conceiving the $3 \mathrm{rd} / 9$ th century as one of transition. ${ }^{77}$ Published texts were certainly widespread, but the concept of the human-authored book as an authority for ${ }^{c} i l m$ was novel and remained an open question. This seems to have influenced al-Ǧăhiz, and closer analysis of his contrary opinions on books and, consequently, foreigners reveals a more complex discourse.

\section{Al-Ğähiz: an ambivalent bibliophile}

Al-Ğāhiz the 'book-praiser' is most evident in al-Hayawān and a shorter epistle on teachers (Risālat al-Mucallimīn) where, in an elaborate analysis of the literate traditions of past civilisations, he marshals 'the book' in a markedly bibliocentric manner. Al-Ğāhiz as 'book-censurer', on the other hand, emerges in al-Bayān wa-l-tabyin and other texts where he expresses different intentions which impacted upon his esteem for the bibliophilic literate epistemology and the relative merits of book producing peoples.

\section{Al-Ǧăhiz: lover of books and bnowledge}

The bibliophilic tenor of al-Hayawān and Risālat al-Múallimīn is well known. ${ }^{78}$ al-Ğāhiz extolled human authored books for their utility, durability and dependability which make them an easy reference, a more efficient store of information than memory (seemingly a direct critique of the aural Islamic tradition) ${ }^{79}$ and the most robust method to preserve information against the ravages of time. ${ }^{80}$ In short, he writes:

Were it not for the book, the stories of the past would become corrupted and the sayings of those absent would be cut off. Your tongue [can only

or mağālis (sessions) with other scholars (G. Schoeler, The Genesis of Literature, 115-17).

77 For the more 'writerly' context of the 'foreign sciences' see S. Toorawa, Ibn Abī Tăhir, 9. He cites Rosenthal's The Technique and Approach of Muslim Scholarship which stresses that 'all branches of literature relied for their preservation on written fixation' which, dating from 1947 seems to overstate the rapidity of the writerly culture's advance in the $3 \mathrm{rd} / 9$ th century (S. Toorawa, Ibn Abī Țāhir, 11).

78 In particular, S. Günther ('Praise to the Book!') and N. Anghelescu (Langage et Culture, 54-66) use excerpts from al-Hayawān to explore the bibliophilic leanings of al-Ğāhiz.

79 Hayawān, 1: 37. Al-Ğāhiz's critique of this tradition is the subject of S. Günther's 'Praise to the Book!', 131, 138.

80 See al-Hayawān, 1: 37-9 (in praise of books generally), 49-51 (merits of writing and the preservation power of the book). 
inform] those present, while the pen [can inform] the absent - those who came before you and those who will come after. Thus, the benefit of the pen is greater, and the public administration (dawāwin) in greater need of it. ${ }^{81}$

With his flamboyant description of the 'book' as 'a vessel, full of knowledge, a container stuffed with cleverness, and a receptacle of mirth and sagacity', ${ }^{82}$ al-Ğāhiz portrays books as quintessential carriers of ${ }^{c} i l m$, akin to the Qur ${ }^{\circ} \bar{a}$ ic kitāb, and in reporting that the Qur ${ }^{\circ} \bar{a}$ and other books of revelation are the best $k u t u b,{ }^{83}$ he implicitly groups all books, terrestrial and divine, in one conceptual category, the Qur ${ }^{\circ} \bar{a} n$ now being the 'best book', and not the 'only book'.

Having established the intellectual value of books, al-Ğāhịiz describes their utility in developing a successful and right-guided society. $\mathrm{He}$ explains that 'spending on books indicates a respect for ${ }^{c} i l m$, and a respect for ${ }^{c} i l m$ indicates the nobility of the soul and its integrity from the intoxication of faults. ${ }^{84} \mathrm{He}$ explicitly lauds this 'bookish' 'ilm, casting it in opposition to jahl (ignorance/passion), as the 'pillar of the soul', the 'origin of all good things', ${ }^{85}$ and the basis for social order:

God does not take ${ }^{c} i l m$ from people. However, He takes away their scholars, and when there is no scholar left, the people choose ignorant rulers who govern without ${ }^{c} i l m$, and they go astray and misguide [their people]. ${ }^{86}$

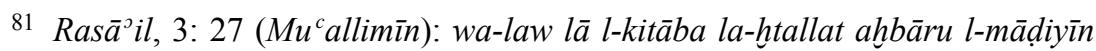
wa-nqața ${ }^{c}$ at ātāru l-ḡāỏibin wa-innamāa al-lisānu li-l-šāhidi laka wa-l-qalamu li-l$\dot{g} \bar{a}^{\top}$ ibi ${ }^{c}$ anka wa-l-māẹ̄ qabla-ka wa-l-ḡābiri bac daka fa-șāra naf'uhu a amma wa-l-dawāwīnu ilayhi afqar. See also Rasā̄il, 4: 245 (Șinācat al-kalām) where book study is expressed as central to the proper learning of language.

82 al-Kitābu wi ${ }^{c} \bar{a}^{\supset}$ un malı̄’un ${ }^{c}$ ilman wa-zarfun hušiya zarfan wa-ină $\bar{a}^{\supset} u n$ šuhina mizāhanan wa-ǧiddan (Hayawān, 1: 32).

83 Hayawān, 1: 59.

84 Hayawān, 1: 41.

85 Such sentiments concerning ${ }^{c} i l m$ are frequently cited in al-Bayān wa-ltabyīn and the Rasā̄il of al-Ğāhiz. See in particular Bayān, 1: 84-5, 1: 257 and 3: 12. The 'pillar of the soul'/ 'imād al-rūh quotation is from Bayān, 1: 77. For the praise of ${ }^{c} i l m$ as the origin of all good things: wa-l- ${ }^{c} i l m u$ așlu li-kulli hayrin wa-bihi yanfașilu al-karamu mina l-lu’ mi wa-l-halālu mina l-harām (Rasā̄o il, 3 : 35, Mucallimìn).

86 Bayān, 1: 257: inna llāha lā yaqbiḍu l- ${ }^{c} i l m a ~ n t i z \bar{a}^{c}$ an yantazi ${ }^{c}$ uhu mina lnāsi wa-lākin yaqbị̣u al- ${ }^{c}$ ulamāo a hattā id̄ā lam yabqa ${ }^{c} \bar{a}$ limun ittahad $r u^{\supset} a s \bar{a}^{\supset}$ a ğuhhālan fa-su ilu fa-aftaw bi-gayri ${ }^{c}$ ilmin wa-ḍallū wa-adallū. 
Taken together, al-Ğāhiz's statements demonstrate that books transcend mere depositories of information: they are symbols for the pursuit of ${ }^{c} i l m$ and prima facie evidence for the existence of culture and learning.

In al-Hayawān, al-Ğāhiz develops this bibliophilic reasoning into a world-historical vision whereby books become the sine qua non of humanity's intellectual development across time and space, which is the basis of his 'universal' bibliocentric outlook noted above. To prove it, he explains that humans, as created by God, are unable to live selfsufficiently and are dependent on one another. ${ }^{87}$ From this principle, he argues that maintaining this necessary contact with neighbours is not always possible, hence the logical necessity of writing to communicate with those who are not immediately present. ${ }^{88}$ Al-Ğāhiiz asserts that groups of people (umam) similarly rely on the passage of knowledge from past societies to advance their own learning and avoid mistakes of the past. ${ }^{89}$ Arguing that books are the only remaining tangible link with the past, ${ }^{90}$ al-Ğāhiz concludes that books vitally maintain the venture of knowledge on earth. ${ }^{91}$ The cycle is also continuous: writing is an 'intellectual duty' for the present in order to edify future generations and allow them to develop ${ }^{c}$ ilm into new horizons. ${ }^{92}$

The elevation of books into vessels of ${ }^{c} \mathrm{ilm}$, and the portrayal of ${ }^{c} \mathrm{ilm}$ as the unifying force underwriting the sweep of human history from its origins and into the future neatly generates a global bibliocentric worldview whereby Muslim civilisation can locate itself as a participant in the historical endeavour of knowledge where each civilisation is a link in a chain soldered by books. Here al-Ğāhịiz presents one of the earliest formulations in Muslim writing of an intellectualised and bibliophilic worldview at its humanistic apogee: inclusive and cosmopolitan.

87 Hayawān, 1: 34-5. The Qurª̄n frequently considers mankind's lack of self sufficiency, although this is adduced as evidence of their inferiority to God (e.g. 92: 8, 96: 6-7). Al-Ğāhiz echoes this principle, but has shifted the emphasis to the need for humans to look for mutual help from each other.

88 Ibid.

89 Hayawān, 1:53

90 Al-Ğāhiz makes this statement on account of books' ability to survive whereas he believed architectural monuments and the other attempts of past civilisations to immortalise their accomplishments are more susceptible to the ravages of time than books. Hayawān, 1: 49-52.

91 Hayawān, 1: 59

92 Hayawān, 1: 60. See ${ }^{\mathrm{c}}$ A. Arḥ̄ila (al-Kitāb, 35-39) for an alternative, though similar reading of al-Hayawān to that presented here. 


\section{Al-Ğāhiz: respect for foreign book-writers}

His intellectualised worldview weaves together the contemporary status of books, opinions on the merits of past peoples and the contemporary translation project into a discourse asserting the primacy of books in knowledge acquisition which enables him to use 'the book' as a means to appraise other peoples, automatically elevating the status of book producers and validating his own 3rd/9th-century adab culture which, via the translation project, was benefitting from past literary heritages. ${ }^{93}$

Since many of the 3rd/9th-century intellectuals were not Arabian, it may seem unusual to refer to the intellectual heritage of Persians and Greeks as 'foreign', however, in light of al-Ğāhiz's intellectualised conception of world history, issues of ethnicity, as noted above, were less concerned with 'blood relation', and more with intellectual achievement. As such, al-Ğāhị's discourse on ethnicities had a rearward looking aspect - the 'Persians' could be viewed as a past civilisation, and understood as contributors in the story of human knowledge production, assessable by the volume of their scholarly heritage. Societies that produced books earned a place for themselves in 'history', while those lacking literate traditions neither learned anything from those before them, nor could bequeath anything to posterity, and so had no place in al-Ǧāḥiz's view of history. ${ }^{94}$ In al-Hayawān, al-Ğāhiz thus commends his book writing intellectual predecessors, expressing his gratitude that Indian astronomy was preserved in their 'scripts' (hut utt) ${ }^{95}$ and professing a high opinion of Aristotle, Plato, Ptolemy and Democritus as pioneers of science and learning. ${ }^{96}$ In light of the close association of books with their authors in the emerging writerly culture, this intellectual, bibliocentric lens rendered foreign societies synonymous with their books. The wise Greek-thinkers and just Persian kings who emerge in Arabic adab as veritable stereotypes of Greeks and Persians

93 Al-Ǧăhiiz relied on these sources himself: Ch. Pellat (The Life and Works, 4-5) notes al-Ğāhị’s exposure to Persian and Indian influence in al-Bașra (where al-Ğâhiz was born) and increasing access to Greek influence in Baghdād (where he lived a long segment of his adult life).

94 The role of the book in establishing the merits of past literate cultures has been similarly considered by N. Anghelescu, Langage et Culture 55-6, 59. She has, however, neglected to consider the negative opinions which al-Ğăhiz expressed about books, and to attempt a synthesis of these paradoxical strands in his thought. Such an exploration and a possible synthesis will be offered below.

95 Hayawān, 1: 36.

96 Hayawān, 1: 52. 
appear to have stepped off the pages of the translated Greek and Persian books and into the imaginations of ${ }^{\mathrm{c}} \mathrm{Abbāsid}$ writers. It is perhaps not coincidental therefore, that medieval Arabic literature generally gives more detailed accounts of the history of Greek books than it does the GrecoRoman political history. ${ }^{97}$ The 'inclusive' aspect of the writerly culture of al-Ğāhiz's day has been identified as the beginning of an increasingly 'secular' 98 (perhaps better labelled cosmopolitan) conception of knowledge in ${ }^{\mathrm{c}}$ Abbāsid circles as a widening audience consumed the knowledge of past peoples by reading their books. Based on the discourse in al-Hayawān, it seems straightforward to conclude that alĞāhiz squarely identified book production with worthy culture and that his bibliophilia transferred smoothly to xenophilia in the case of nonArabic book-producing peoples. ${ }^{99}$ But this discourse on the centrality of books and praise for book producing people also displays a more pointed self-serving element underlying his seemingly effusive bibliophilic cosmopolitanism.

Given that the Muslim civilisation of al-Ğāhiz's day had built its intellectual edifice upon the collective traditions of Arabians, Persians, Indians and the Rūm, it is entirely logical that al-Ğāhiz would commend these peoples on the basis of books. His discourse asserts that their books were 'worth reading' and so argues for the usefulness of their further translation and study in ${ }^{\mathrm{c}} \mathrm{Abba}$ sid Iraq. While the original authors were praised as a by-product of this argument, perhaps more importantly for al-Ğāhiz's purposes, his equation of reading with the concept of social progression over time enabled him to theorise that his culture, which both consumed books of the past and wrote new books, stood at the pinnacle of human progression: the legitimate and worthy successor to

97 While fourth-century Muslim world histories such as al-Ṭabarī, alMas ${ }^{\mathrm{c}} \overline{\mathrm{u}} \mathrm{d} \overline{1}$ or al-Maqdīsī give fairly sketchy accounts of Roman Emperors and Greek kingdoms, their contemporary Ibn al-Nadīm narrates in fine detail the transmission of Greek texts from their ancient origins to their Arabic translations (e.g. for medical texts see Fihrist, 345-6). Further analysis of this discrepancy would be interesting to explore, but it is beyond the scope of this paper.

98 S. Toorawa, Ibn Abi Tăhir, 129. Toorawa notes that the term 'secular' is of questionable application here, but intends by this the development of an $a d a b$ culture in distinction to the scholarship specialised in the Islamic traditions.

99 Perhaps this accounts for al-Ğāhiz's mention in his epistle on the 'Virtues of the Blacks' that the term for the written text of the Qur'ān, muṣhaf, derives from 'Habāsh̄̄' origins which thereby attempts to delineate some literate element in African culture, and thus a point of merit (Ras $\bar{a}^{\circ} i l, 1: 202$, Fahr al-sūiān). 
its polyglot past. This has been identified as one of the centrepieces of alĞāhiz's thought and the theme of al-Hayawān. ${ }^{100} \mathrm{Al}$-Ğāhiz, in the guise of a bibliophilic xenophile could thereby claim that the ${ }^{\mathrm{c}} \mathrm{Abba} s i d$ scholars, via their translation of Persian, Greek and Indian sources had collated the entirety of humanity's knowledge and could legitimately consider themselves the most erudite nation yet. His outward cosmopolitan 'humanism'101 may thus be more inward looking and selfserving, linking with al-Ğāhiz's discourses on ethnicity as an Arabian partisan in al-Bayān wa-l-tabyinn. Pellat observed this tendency and related it to the character of $a d a b$ culture to 'prendre de tout un peu' and to borrow from foreign cultures without accepting their superiority to Arab culture. ${ }^{102}$ This is an accurate observation, but these leanings of alĞāhiz are tied to a more multifaceted theory about books and knowledge in general. The anti-book, xenophobic trend in his writing now calls for examination.

\section{Al-Ğạhiz the book cynic}

Al-Ğāḥiz's bibliophilic introduction to al-Hayawān was a polemical treatise. He draws our attention to this, noting that he wrote it in selfdefence against those whom he described as unjust critics of his writings. ${ }^{103}$ Furthermore, the influence of al-Mahāsin wa-l-Masāwi ${ }^{\supset}$ genre has been noted as operative in al-Hayawān more generally, which cautions an uncritical acceptance of the content of al-Hayawān at face value. ${ }^{104}$ His extravagant description of books as 'the most humble teacher; the most capable companion; the least boring and least grating friend...the most ready support', and his florid analogy of the book as a tree having the 'longest lifespan and sweetest fruit which is most easily

100 Al-Ğāhiz is typically associated with this perceived cosmopolitan trend in Muslim culture of the 3rd/9th century (Ch. Pellat, 'al-Djāhiz', 387; N. Anghelescu, Langage et culture, 54-5). Enderwitz proposed, based on analysis of al-Hayawān, that adab represents a fusion of the Arabian with the non-Arab cultural heritage and that al-Ğăhiz considered $a d a b$ books as the highest forms of historical human expression, behind only the Qur'ān (S. Enderwitz, 'Culture History and Religion', 235-237).

101 A term applied to al-Ğāḥiz in Al-Ğăhiz: a Muslim Humanist for our Time ('Introduction', v) and to al-Ğāhịị's cultural milieu by N. Anghelescu, Langage et Culture, 63, 66.

102 Ch. Pellat 'Djāhiz et la littérature comparée', 95-6, 98.

103 Hayawān, 1: 7-14.

104 I. Gériès, 'al-Maḥāsin wa-1-Masāwī', 1224. 
picked' 105 are all specifically intended to rebut the critic of his books. ${ }^{106}$ In short, by promoting the virtues and social utility of books in general, al-Ğāhiz could defend his reputation as a writer and argue that his books ought to be read in the most positive possible light. ${ }^{107}$ Al-Ğāhịiz certainly saw himself as a worthy participant in an intellectual heritage mediated by books, but he neither claims that all books are of equal merit nor that all writers are deserving of equal esteem.

Even in al-Hayawān, al-Ğạhiz notes that other forms of communication are potentially as useful as books (depending on the circumstance), and that the pen and tongue are balanced in virtue, making no explicit statement of the written word's greater merit. ${ }^{108} \mathrm{He}$ expressly states that his only intention in writing al-Hayawān's introduction was to 'expound the virtues of books'. ${ }^{109}$ The fuller exploration of communication and knowledge hinted in al-Hayawān is taken up in al-Bayān wa-l-tabyin where his treatment of books is not quite so effusive.

Even before turning to his other writings, a reader of al-Hayawān can perceive various criticisms of books. Al-Ğăhiz censured the books of the zanādiqa (Zoroastrian Persians), lamenting their lack of ${ }^{c} i l m$, poor style and dismissing their stories of heroes, demons and wondrous adventure (à la Šăhnäme) as 'idle, inept legends' lacking 'useful' knowledge, wisdom, witticism or anecdote. ${ }^{110}$ In his opinion, expenditure on these books is wasteful: they are ğăhil (ignorant), misguiding readers away from both self-improvement and religious enlightenment. ${ }^{111} \mathrm{Al}$ -

105 Hayawān, 1: 33-4.

106 Hayawān, 1: 23: lacalla ra yaka inda dālika an yatahawwala waqawluka yatabaddal (that perhaps your opinion [after reading this book] will transform and your [previous critique] will change).

107 Hayawān, 1: 31.

108 Hayawān, 1: 38, 50-1.

109 Innamā qașdunā bi-kalāminā ilā l-iḩbāri can fậ̣lati l-kitāb (Hayawān, 1:38).

110 Al-Ğāhiz describes the content of these books as 'hadr, wa-'iyy wahurāfa', and the material they lack includes: matal să $\bar{a}^{3}$, habar tarīf, șan ${ }^{c} a t$ adab, hikma garība, falsafa (Hayawān, 1: 42)

111 Al-Ğāhiz (Hayawān, 1: 43) explains this though the rhetorical question: fa-ayyu kitābin ağhalu wa-ayyu tadbīrin afsadu min kitābin yūğibu calā l-nāsi l-

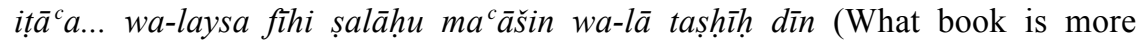
ignorant, or what work is more corrupting than a book which demands obedience from its readers, but lacks any element of bettering their lives or edifying their religion!?). 
Hayawān also invokes ğahl to describe books written by Muslims which are censured as 'trashy' (kutub al-furrā $\dot{g}$ al-hulac $\bar{a}^{\jmath}$ ) or as 'diversions and banter' (kutub al-malāhì wa-l-fukāhāt). Similarly, he relates criticism of books authored by those with bellicose agendas, shallow values or affected by the 'rancour of the ğăhiliyya'. ${ }^{112}$ Al-Ğāhiz narrates these opinions from the voice of a (hypothetical) critic, but it indicates what he conceived as the antithesis of his books. While we have seen that al-Ğāhiz equated some books with the Qur ānic kitāb, i.e. as symbols of cilm, this was by no means a blanket endorsement for all books.

Outside of al-Hayawān, we find al-Ǧāhiz denigrating the 'writerly culture', censuring those who read excessively and reproduce 'book language' as mere followers $\left(t \bar{a} b i^{c}\right),{ }^{113}$ especially criticising the $k u t t a \bar{b}-$ the state secretaries whom modern scholars consider to be among the first movers towards the writerly culture at the end of the $2 \mathrm{nd} / 8$ th century. ${ }^{114}$ These negative aspects of the writerly culture justify, for alĞāhiz, why God chose not to bestow skills in al-hatt (handwriting) on Muḥammad. ${ }^{115}$ And so al-Ğāhị paradoxically undermines alHayawān's framework for the transmission of knowledge across the sweep of human history by literate scholars.

Al-Ğāhiz hints at further suspicions regarding books in al-Hayawān in an insightful passage where he highlights the perilous journey of 'book knowledge' across time through the hands of copyists and translators. In particular, we read that the dual requirements for an ideal translator - (a) linguistically wholly proficient in the original and target language, and (b) intellectually on par with the authors whom he translates - can only exist in theory. ${ }^{116}$ Consequently, al-Ğāhiz notes that translations even in the 'straightforward' fields of geometry and philosophy (al-handasa wa-l-falsafa) can be found lacking, while errors are almost guaranteed in religious sciences, where precision and knowledge are paramount. ${ }^{117}$ In short, books emerge as twisted, corrupt and unreliable conveyors of

112 Hayawān, 1: 23. Here al-Ğāḥiz alludes to the Qur ānic expression (48:

26) 'Hamiyyat al-ğāhiliyya'.

113 Rasāil, 2: 192(Kuttāb).

114 See G. Schoeler, The Genesis of Literature and Ch. Pellat, The Life and Works, 4.

115 Rasā'il, 2: 189-90 (Kuttāb).

116 Hayawān, 1: 53-4.

117 Ibid. 
past knowledge as they pass through the 'criminal hands' of copyists. ${ }^{118}$ The above passage is enigmatic: it is not the direct speech of al-Ğăhiz, but again a 'quotation' from a hypothetical critic defending the Arabic oral poetic tradition. However, al-Ğāhiz does not refute any of these arguments and in fact adopts them himself elsewhere. ${ }^{119}$ Thus, with his signature ambivalence, al-Ğăhiz leaves to the reader the task of resolving the question of whether books can or cannot accurately transmit ${ }^{c} \mathrm{ilm}$. Akin to the linguistic quandary that bedevils translation, al-Ğāhiz also cites the negative effect of writerly culture on language generally. He explains that book culture tends towards takalluf (unnatural mannerism) ${ }^{120}$ and readers who fashion their speech after books develop stiff and artificial language. ${ }^{121}$ Surprisingly for a bibliophile, al-Ğāhiz deems written language an inappropriate guide for good rhetoric!

Al-Ğāhiz's well-reasoned bibliophilia and praise of books as symbolic embodiments of intellectual progress are therefore checked by his apparent belief that reading books neither guarantees accurate transmission of knowledge nor necessarily enables self-improvement, and that writerly culture can lack creativity and vitality. This sentiment closely mirrors a negative opinion of foreign civilisations and their books, which emerges from al-Bayān wa-l-tabyīn and other Ğāhizizian epistles.

Al-Ǧāhiz: censurer of book-writing foreigners

Al-Ğāhiz's denigration of the literate foreign cultures which he elsewhere extoled is less commented upon in modern scholarship. ${ }^{122}$ Regarding the Sasanian Persians, al-Ğāhị criticised their books and intellectual

118 Hayawān, 1: 55: lā yazālu al-kitābu tatadāwaluhu l-ayd̄̄ l-ğāniya (the book continues being passed down by 'transgressing' hands [of copyists]).

119 See his discussion of problems with translations from Persian and the Rūmī language and problems with Christian theology, discussed in the next section and note 150 , below.

120 Bayān, 3: 29.

121 This even includes reading books authored by eloquent and/or wise

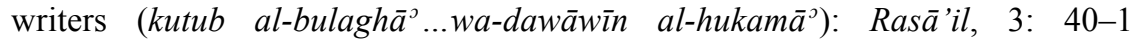
(Mucallimin $)$.

122 The only article of which I am aware which specifically considers alĞāhiz's negative opinions of Persian, Indian and Rūmī books is Ch. Pellat's 'Djāhiz et la littérature comparée' where Pellat attributes these comments to alĞāhiz's method of grappling with the $a d a b$ culture's integration of foreign ideas. This shall be further considered below. 
heritage. He considered their books exhibit a laboured style, which he attributed to the Persian authors' lack of natural brilliance and linguistic spontaneity, as, in his view, they copied from each other. ${ }^{123}$ Further, he cast doubt on the authenticity of the translated Persian books circulating in ${ }^{\mathrm{C}} \mathrm{Abba}$ sid Iraq, insinuating that they may have been, in part, forged by translators in the early ${ }^{\mathrm{C}} \mathrm{Abb} \overline{\mathrm{a}} \mathrm{sid}$ era. ${ }^{124}$ In this argument, he adopts the reasoning of that hypothetical 'book critic' from al-Hayawān: mistrusting books capacity to faithfully convey ${ }^{~} i l m$ across time, and denying the 'Persian book' as a basis for praising the past Persian heritage.

Having discredited Persian books, al-Ğāḥiz censures his contemporaries who based their knowledge upon them in preference to the Qur ${ }^{\circ} \bar{a}$ and hadit. ${ }^{125}$ Repeating his critique of the book as ğahl, alĞāhiz laments that the knowledge gained from Persian books is in fact gahli26 and sharply rebukes Ibn al-Muqaffa ${ }^{c}$, the epitome of the $2 \mathrm{nd} / 8$ thcentury Persian ${ }^{\mathrm{C}} \mathrm{Abbāsid}$ scholar/translator who championed Sasanian books and culture. ${ }^{127}$ Evoking the Qur ${ }^{\circ} \bar{a}$ (62:5), al-Ğạhiz relates an anecdote comparing Ibn al-Muqaffa ${ }^{c}$ to a donkey weighed down with books carrying much ${ }^{c} i l m$, but not benefiting in the least: 'his knowledge made him weak, his reason baffled him, his wisdom blinded him and his insight confused him'. ${ }^{128}$ Persian books in al-Ğāhiz's estimation are thus a far cry from authoritative, enlightening sources and there is little praise of Persian culture here.

Al-Ğāhiz's censure of the ancient Greeks again focuses on a criticism of their writing style. He claims that their knowledge of philosophy and logic did not translate into elegant expressions, and that despite their theoretical understanding of language, the Greeks (al-Yünāniyyūn) did not produce well-formed speech in practice (pace Demosthenes et al, of whom al-Ğāhiz makes no mention). ${ }^{129}$ Similarly, al-Ğāhị claimed that

123 Bayān, 3: 28.

124 Bayān, 3: 29.

125 Examples he gives of these Persian books are the collections of anecdotes from the Sasanian king Ardašir, sayings of the vizier Bozorgmehr, Kalīla waDimna and the religious books of Mazdak. See Rasā̄il, 2: 191-2 (Kuttāb).

126 Ibid., 2: 194-5.

127 Ibid., 2: 192, 195. Also, al-Ǧāḥiz lists Ibn al-Muqaffac's Arabic language book al-Adab (which is commonly known today as al-Adab al-kabirr) among the Sasanian books of 'substandard' 'ilm.

128 Rasa $\bar{a}^{\supset} i l, 2: 195$ (Kuttāb).

129 Bayān, 3: 27-8. He specifically notes that Șāḥib al-manțiq (a sobriquet for Aristotle, see G. Lecomte, Ibn Qutayba, 191-2) was a poor speaker. 
Ancient Greek society as a whole, notwithstanding the intelligence of their scholars, failed to make any practical application of their theoretical knowledge and wisdom. ${ }^{130}$ Knowledge has no civilisational benefit if unapplied, al-Ǧăhiz argues, and accordingly, when comparing the Greeks to other peoples (umam) such as the Chinese, Persians, Turks and Bedouin Arabs $\left(A^{c} r \bar{a} b\right)$, he concludes that the Greeks, for all their wisdom, do not deserve a higher status. ${ }^{131}$ Contemporary Byzantine (Rūmī) civilisation faired worse. Since Ancient Greek (al-Yūnān) writers lived in the distant past, al-Ğāhiz rejects the possibility that their books and intellectual heritage could be claimed by contemporary generations of Byzantines. According to al-Ğāhịiz, contemporary Rūmī literary production was negligible and their language was so different from Classical Greek that they could not possibly invoke its past glories for their benefit. ${ }^{132}$

As for the Indians, al-Ğāhiz less frequently discusses them in his surviving writings, ${ }^{133}$ but his extant appraisal of their culture similarly contains unenthusiastic evaluation of their books, which he describes as lacking both rhetorical power and creative spirit. They 'only contain ancient meanings, not attributable to one scholar...they are merely heritage since time immemorial, well known, well rehearsed'. ${ }^{134}$

Towards a resolution

Al-Ğāhiz's paradoxical style, the relative obscurity of his life and uncertain chronology of his writings ${ }^{135}$ complicate a reconciliation of his 'book loving' and 'book hating' tendencies. But patterns in his seemingly contradictory statements indicate a certain coherency within a complex web of issues. His opinions about books varied, but al-Ğāhị was clearly preoccupied with books, indicating the maturation of the writerly culture in the 3rd/9th century. His analysis of foreign peoples also frequently cited books: whether al-Ğāhị wished to praise or

130 Rasā̄il, 3: 214-15 (Manāqib al-Turk).

131 Ibid., 216-18. In al-Ǧāhị's opinion, here, these peoples excelled in a limited number of fields, but they failed to become all-round achievers.

132 Rasā $\bar{a}^{\circ}$ l, 3: 314-15 (al-Radd ' alā l-Nașāra).

133 He apparently wrote books in which he considered their religious beliefs and idolatry which he cites in Hayawān (1: 8-9). These are now lost and alĞāhiz’s's conclusions are unknown.

134 Bayān, 3: 27: ammā l-Hindu fa-innamā lahum macānin mudawwanatun wa-kutubun muhalladatun lā tuḍāfu ilā rağulin macarūf... wa-innamā hiya kutubun mutawārițatun wa-ādābun ${ }^{c}$ alā wağhi l-dahri sā̃ iratun madkura.

135 Ch. Pellat, The Life and Works, 10-14. 
denigrate groups, he marshalled 'the book', categorically denigrating those peoples whom he believed possessed no literary culture, ${ }^{136}$ and while privileging book producers, he cited shortcomings of their books as a means to criticise them. His critiques and praises of both books and foreign peoples also revolve around questions of language. Closer consideration of al-Ğăhiz's conception of the praiseworthy book and the position of language in his worldview points towards a possible explanation of his paradoxical statements on literary culture.

The ideal book: 'meaning and speech'

Al-Ğāḥiz defined the ideal, unimpeachable book (muhkam, mutqan) $)^{137}$ as having 'sound judgment, like the smooth face of bare rock, with precise and elegant meanings; and fine and eloquent wording. ${ }^{138}$ The allusions to good 'judgement' and 'meaning' reflect al-Ğāhiziz's belief that books can be repositories of authoritative knowledge, as discussed earlier. His inclusion of 'wording' (lafz), however, introduces a second component: 'expression' (bayān) and indicates the centrality of language in the constitution of a worthy book. The twin roles of ${ }^{c} i l m / k n o w l e d g e$ and bayān/expressive language as the basis of good communication are a major theme of al-Bayān wa-l-tabyīn and are similarly, though more briefly described in his other major work, al-Hayawān. ${ }^{139}$ Al-Ğāhiz's opinions of bayān have frequently been discussed in medieval and

136 Even in Manāqib al-Turk, where he makes a fairly vigorous (and perhaps politically motivated, see above) defence of Turks, al-Ğāhiz does not promote them above book producers. Their skill in war and hardy attributes are praised, and while he equates their excellence in war with the Greek excellence in philosophy and the Sāsānid Persian achievements in statecraft, the Turks are not raised above these two (book writing) cultures ( $\left.\operatorname{Ras} \bar{a}^{3} i l, 3: 217-18\right)$. Outside of the Manāqib, the Turks are never listed among 'noteworthy peoples'. The nonbook producing pre-Islamic Arabians are a special case, considered below.

137 Rasā $^{\circ}$ il, 1: 350 (al- ${ }^{c}$ Adāwa wa-l-hasad).

138 Rasā $\bar{a}^{i}$, 1: 351 (al- ${ }^{c}$ Adāwa wa-l-ḥasad): al-kitābu... muḥsafan ka-annahu matnu hağarin amlasa bi-ma ānin latịfatin muḥkama. This is, naturally(!), a description of one of his own books, though it conveys the ideal to which he strove in his own writing.

139 The similarity of al-Ğāhiz's approach to bayān (Bayān, 1: 75-88 and passim and Hayawān, 1: 29-31) is important as it implies a (rare) continuity and stability in al-Jāhiz's thought. The books were written at different times - alBayān before 237/851 and al-Hayawān before 232/846 - (Ch. Pellat, 'Nouvel essai', 133, 139) and with different aims, but notwithstanding this, their treatment of bayān is very similar. 
modern scholarship. ${ }^{140}$ Taking Montgomery's and Behzadi's recent analysis of bayān together, it becomes clear that al-Ğăhiz afforded it importance not just as an 'intellectual playground', ${ }^{141}$ but as the cornerstone for all aspects of life including the means to understand God and both the nature and meaning of the Qur ${ }^{\circ} \bar{a}$ in $\mathrm{Mu}^{\mathrm{c}}$ tazilite theology.

Such a profound appreciation for good style and appropriate language consequently had important ramifications in many of al-Ǧāhiz's intellectual preoccupations, and his promotion of style and clarity of expression as a primary component of the 'worthy book' seems the product of his deep-rooted interest in bayān. Here the specific booklanguage nexus will be further explored to understand how al-Ğāhiz's opinions took their particular shape and to demonstrate how his seeming ambivalence regarding the book and foreign peoples is in fact part of a more coherent discourse.

Al-Ğāhiz applied his belief in the supreme importance of communication directly to his intellectualised vision of world history. Whereas in al-Hayawān he emphasised the role of books in the historical venture of knowledge, it seems incorrect to assume that he considered books as the sole embodiment of this process. As noted above, even in al-Hayawān, he criticised the shortcomings of some books, and in alBayān wa-l-tabyin, he more explicitly describes why. While books convey 'knowledge', al-Ğāḥiz stresses that appropriate and clear expression (bayān) is necessary to faithfully transmit any learning. Badly or imprecisely written books distort the knowledge they contain and risk misunderstanding. Such books categorically fail to transmit knowledge, and hence al-Ğăhiz concluded that it is bayān, clear expression, that brings ${ }^{c} i l m$ to life. ${ }^{142}$ Al-Ğāhiz believed that all of the different forms of communication (which he enumerates as speaking, writing, computation, gesturing and metaphor) can convey ${ }^{c} \mathrm{ilm}$, and their relative suitability

140 See L. Behzadi, 'al-Ğāhị and his Successors' and Sprache und Verstehen. Also, the recent series of articles by Montgomery have carefully demonstrated the theological leanings of al-Ğāhiz's's 'nature/speech' dichotomy which figure prominently across his writings ('Speech and Nature').

141 L. Behzadi, Sprache und Verstehen, 173.

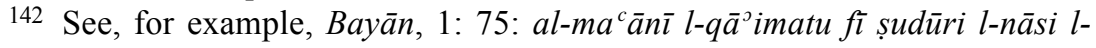
mutașawwaratu $f_{\imath}$ aḍhānihim... mastūratun hafiyyatun wa-bacīdatun waḥšiyyatun wa-maḥğūbatun maknūnatun... wa-innamā yūhȳ̄ tilka l-macāniya dikruhum lahā wa-ihbāruhum canhā ('the meanings in the souls of men and conceived in their minds... are hidden and obscured, remote and inaccessible, veiled and concealed...these meanings are only brought to life by [the scholars'] mentioning of them and informing of them'). 
depends on the circumstances. ${ }^{143}$ Sometimes hatt, the written word, is ideal, but al-Ğāhiz maintains that clarity of expression trumps the medium: the correct conveyance of ${ }^{c} i l m$ depends on the selection of the best method for the given circumstance. No single method suits all occasions: "the revelation of meaning occurs to the extent of semantic clarity, accuracy of expression, appropriate epitomisation [of meaning], and precision'. ${ }^{144}$ The transfer of knowledge, therefore, cannot logically be the exclusive preserve of literary culture.

For al-Ğạhiz, the perpetuation of intellectual culture via the communication of ${ }^{c} i l m$ through clear bayān begins with the Qur ān since its excellent bayān is the means by which God teaches His ${ }^{c} i l m$, and ideal bayān belongs to God. ${ }^{145}$ But al-Ğāhị cites a definition of humans as the 'living, clear speaking (mubin)' ${ }^{146}$ and so allows them to achieve degrees of eloquence too. ${ }^{147}$ Al-Ğāhị thereby contrasts bayān with ${ }^{c} i y y$ (inhibited speech) just as ${ }^{c} i l m$ opposes ğahl. ${ }^{148}$ As we have seen, he appraised books by their language and meaning together, and so it would appear, he appraised humans.

Crucially, al-Ğāhiz ventures that the concordance of sound meaning and correct expression in human communication approaches the Divine:

[t] he best speech is that which is brief and obviates the need for protracted expression and the meaning of which is apparent in its expression; Almighty God grants [such speech] some of His loftiness and bestows upon it the light of His wisdom, according to the good intentions and piety of the speaker. ${ }^{149}$

143 Bayān, 1: 76-80 and Hayawān, 1: 29. In both texts, writing is generally lauded as one of the most efficient means of effecting good bayān, but it is not necessarily the most eloquent.

144 Bayān, 1: 75: 'alā qadri wuḍūhi l-dalālati wa-ṣawābi l-išārati wa-ḥusni l-ihtișāri wa-diqqati l-madhali yakūnu iẓhāru l-macnā.

145 Bayān, 1: 8-9.

146 Bayān, 1: 77: hayawān nātiq mubīn, a marked, if subtle development from the usual Aristotelian conception of humans as zoon logikon, often construed as 'rational animal'.

147 Bayān, 1: 8.

148 Ibid.

149 Bayān, 1: 83: wa-aḥsanu l-kalāmi mā kāna qalīluhu yuġn̄̄ka can kațīihi wa-ma nāhu fì zạhiri laf̧̣ihi wa-kāna llāh cazza wa-ğalla qad albasahu mina lğalālati wa-ğaššāhu min nūri l-ḥikmati calā hasabi niyyati șāḥibihi wa-taqwā $q \bar{a}^{\curvearrowright}$ ilihi. 
Books and human activity thereby become both intellectually and linguistically construed. The Qur ${ }^{\top} \bar{a}$ represents the ideal concordance of meaning and language, but the model permits terrestrial communication to be appraised to the extent it approaches the Quranic standard.

Why al-Ğāhiz emphasised the centrality of bayan in the venture of knowledge and effectively promoted it above books may be explainable in part by the status of writerly culture in his day. As noted above, notwithstanding the growing importance of books in 3rd/9th-century intellectual circles, the 'silent' book had not replaced aural methods of knowledge transmission, and a respect for oral/aural skills and style would linger in Muslim culture for centuries. ${ }^{150}$ As such, emphasis on oral and other non-written forms of communication is natural, and an exclusive praise of books as stand-alone authorities of ${ }^{c} \mathrm{ilm}$ would have seemed radical and perhaps nonsensical. Consequently, writing is a component of bayān, and indeed is privileged by the bibliophile alĞāhiz, but the written word is not paramount, as one may expect could be the case in a more thoroughly 'literate' intellectual milieu. The as-yet immature writerly culture and writerly styles of communication may thus have curbed al-Ğāhị’s's bibliophilia.

In addition to these factors, issues of ethnicity also appear which point to another intertwined agenda at work in his thoughts on bayann and, as a consequence, books in general. At the centre of this lies al-Ğạhiz's acceptance of the Qur'ān's stylistic pre-eminence, which is uncontroversial. However, he elevates this into an ethnic discourse whereby his conception of bayān shifts from pure stylistic analysis into a means to create a hierarchy of world languages. Inasmuch as Arabic is the language of the Qur ${ }^{\circ} \bar{a}$, al-Ğāhiz asserted that Arabic qua language, must possess the best potential for bayān. He explains:

There is no language on earth more enjoyable, elegant or sweet to hear, more intimately connected with clear rational thought or more expressive than that heard from the correct-speaking, sound-minded Arabians ( ${ }^{3} a^{c} r \bar{a} b$ ) and eloquent scholars. ${ }^{151}$

150 For the persistence of the 'oral' aspect of learning into the late medieval period, notwithstanding the penetration of books in all fields of scholarly activity, see J. Pederson, The Arabic Book, 17, 31-6.

151 Bayān, 1: 145: innahu laysa fì l-arḍi kalāmun huwa amtac $u$ wa-lā ānaqu

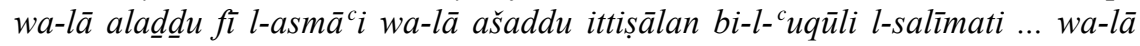

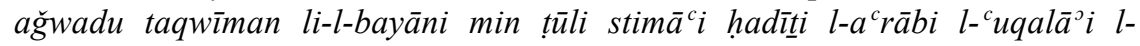

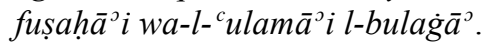


Al-Ǧāhịiz's intellectual elitism is again at work here; his conception of bayān promotes the Arabians and his own 'Arabised' scholarly community above all others and disadvantages foreign cultures from the outset. Al-Ğāhiz directed this thought to its logical conclusion: applying bayān to a global worldview, he conceded that all peoples can express themselves, even if only by 'crude expression, poor meaning and 'brutish language', ${ }^{152}$ but in his opinion, only Arabic speakers are truly proficient in bayān, while a group of 'foreigners' (here he means the Persians) also had some, though lesser, expertise. ${ }^{153}$ The 'four noteworthy peoples' (madhkürün) of book producers, thus reduce to at most two (more likely one-and-a-half) when the secondary hurdle of bayān is erected before them.

The practical effects of this were far reaching. Speakers of imperfect languages, according to al-Ǧāhiz’s logic, necessarily possess imperfect knowledge: their expressions cannot accurately articulate what they intend to say. Hence al-Ğạhiz attributed 'errors' of Christian theology (i.e. where Christian dogma differed from Islamic) to Rūmī linguistic deficiencies which prevented the accurate conveyance of the teachings of Jesus. ${ }^{154}$ In contrast, al-Ğāhiz believed Arabic speaking theologians were better protected from theological error by the clarity of the Arabic language. ${ }^{155}$ The addition of the linguistic parameter in judging knowledge starkly handicaps non-Arabic speaking peoples and enables al-Ğāhiz to acknowledge their literary heritage while maintaining that their books lack the fundamental linguistic component of the kitāb muhkam mutqan, which he believed only Arabic could truly produce, and so justifying his negative opinions of non-Arabic books

152 Bayān, 3: 12-13: hattā inna l-Zanğa maca l-ġatārati... li-tuṭīla l-hnuṭab... wa-in kānat ma ${ }^{c} \bar{a} n \bar{h} \bar{a}$ ağfā wa-à்laẓa wa-alfāzuhā ahțala wa-ağhala.

153 Al-Ğāhiz does not specify particular foreign groups in his, stating: 'with [bayān] the Arabs are duly proud and with bayān some of the 'A ğam claim precedence' (wa-bi-d̄ālika [al-bayān] tafäharat al- ${ }^{c}$ Arabu wa-tafāọalat așnāfu l- ${ }^{c}$ Ağam, Bayān, 1: 75). Later on he specifies that the Persians are the other group who maintained an acceptable standard of bayān, although this is expressly inferior to the Arabic (Bayān, 3: 27-9).

154 See Rasā̄il, 3: 334 (al-Radd ' alā l-Nașārā).

155 Ibid., 337. Al-Ğāhiz did concede, alluding probably to the kalām debate in his own society, that not all Arab scholars understand the most complex points of theology because even the bayān of Arabic, as written by humans, can fall short of conveying such complex ${ }^{c} \mathrm{ilm}$. This, however, was not, for al-Ğāhìiz, a weakness of Arabic, but rather, a warning to scholars of the almost certain failure that will befall theological speculation in any other tongue. 
Arabians and al-Ǧăhiziz's emphasis on Bayān

While later medieval commentators attributed al-Ğāhiz's partisanship of the Arabic language to his defence of the Qur ${ }^{\supset} \bar{a}$, and while very similar arguments for the primacy of Arabic among world languages would appear in the $i^{c} \bar{g} \bar{a} z$ al-Qur ${ }^{3} \bar{a} n$ genre ${ }^{156}$, this is unlikely the only or indeed primary reason for al-Ğāhịiz's stance. Al-Bayān wa-l-tabyīn does not particularly defend the Qur ${ }^{\circ} \bar{a} n$ - perhaps he felt it could handle such matters itself 157 - but instead, as noted by Pellat in 'Djāhiz et la littérature comparée' and Behzadi in Sprache und Verstehen, it marshals arguments for a cultural defence of the Arabs. Indeed, as Behzadi argues, al-Ğāhiz utilised bayān for deeper purposes than merely asserting Arabian superiority, but he certainly found bayān a very useful tool in $\check{s}^{c} \bar{u} b \bar{l}$ arguments, and, if we consider how his conceptions of bayān and the Arabians fit into the context of books, we can see how the proArabian foundation of al-Ğāhiz's bayān is in fact paramount. The Kitāb $a l^{c} a s ̦ \bar{a}$ (The Book of the Stick), the most expressly pro-Arabian tract in al-Bayān wa-l-tabyinn, 'also contains some of al-Ğāhịiz's most detailed statements on both books and bayann. Indeed, the precise way in which his conception of bayān interacts with writerly culture and the cultural defence of the Arabians seems a good indication that these debates were intimately related. 'Abbāsid scholars believed that the Arabians lacked a 'book culture' in pre-Islamic times, ${ }^{158}$ yet these 'bookless' Arabians

156 The study of the inimitability of the Qur ${ }^{\circ} \bar{a}$. See the defence of the Qurª̄n by al-Bāqillān̄̄ (d. 403/1013) which utilises the same linguistic arguments as al-Ğāhị and al-Bāqillānī similarly dismisses the merits of foreign languages and their books ( $I^{c} \check{g} \bar{a} z$ al-Qur $\left.{ }^{\supset} \bar{a} n, 29-32\right)$. The opinion of al-Ğurğann̄ regarding al-Ğāhiz and defence of the Qur ${ }^{\circ} \bar{a} n$ is discussed by L. Behzadi, 'AlĞāhiz and his Successors', 129-30.

157 He does expressly note the superiority of the Qur ān's language which constitutes evidence of its Divinity (Bayān, 1: 383), but a purposeful linguistic defence of the Qur ${ }^{\circ} \bar{a}$ is not expressed as a primary concern of al-Bayān wa-ltabyīn as it would become in the later $i^{c} \check{g} \bar{a} z$ al-Qur $\bar{a} n$ books of the 4th and 5 th centuries.

158 Much has been made in Western scholarship of certain references to writing materials in pre-Islamic poetry and the odd treaty which the Islamic tradition informs us was 'written'. These oft repeated references concerning literacy in pre-Islamic times have overshadowed the lack of any admission, rightly or wrongly, by ${ }^{\mathrm{c}} \mathrm{Abba}$ sid scholars of the existence of significant literacy in pre-Islamic Arabia. See, for example, Ibn Qutayba's Kitāb Fadl al- ${ }^{c}$ Arab wal-tanbìh 'ala 'culümihā (Virtue of the Arabs and an Explication on their Sciences) where he lists the major fields of pre-Islamic ${ }^{c} i l m$. Writing is absent, the closest is a description of hatt defined as divination via making lines in the 
under the flag of Islam conquered ancient and learned civilisations. The incongruity of the ratio between Arabian military strength and their literacy would become problematic as the 'book' began to be culturally revered in the maturing writerly environment of the 3rd/9th century. When the parameters for esteem and power no longer rested on the force of arms alone, ${ }^{159}$ the descendants of the 'literate' Persians, Greeks and Indians could marshal the new 'bookish' benchmarks to claim their heritage was superior to the Arabians whose lack of an ancient literary tradition became an obvious source of embarrassment.

By stressing the dual intellectual and linguistic foundation of the 'praiseworthy book', and by focusing on the importance of bayān in underwriting 'ilm, al-Ǧāhiz articulated a firm argument for a nonbookish conception of ${ }^{c} i l m$. He pursued this reasoning and defined the ideal bayān as epitomised in spontaneous good speech (badīha, irtiğ $\bar{a} l$ ) the attributes of skilled orators; while chiding the studied affectation (takalluf) of written language. ${ }^{160} \mathrm{He}$ thus ventured that the best language actually has no need for books and so deftly parried any cultural disgrace attaching to the 'bookless' pre-Islamic Arabians: their lack of a literate tradition was transformed into a cultural strength. Al-Ğāhiz frequently cited the above conception of bayan to laud the Arabians and maintained that their eloquent speech was an inborn virtue, ${ }^{161}$ a linguistic genius born from their desert environment, while he expressly denigrated the retrograde language of urban dwellers. ${ }^{162}$ In sum, the non-bookproducing Arabians emerge at the summit of knowledgeable peoples for their lack of books was more than compensated by their excellent bayān. Al-Ğāhiz could cogently demonstrate that their ${ }^{c} i l m$ was an ${ }^{c} i l m$ of the most useful order, expressed, as it was, in what al-Ğāhiz deemed the most eloquent language. Simultaneously, the conquered non-Arabs and

sand (Fadl, 143). Hattāt in pre-Islamic lore meant this sort of diviner, not the modern concept of a calligrapher (ibid.)!

159 Military power was, by the $3 \mathrm{rd} / 9$ th century, considered the preserve of the Turks whom al-Ğāhiz noted for their martial abilities (cf. his Manāqib alTurk), but this did not elevate them to the tier of 'noteworthy peoples'.

160 Bayān, 3: 28.

161 Ibid.

162 Al-Ğāhiz commonly alludes to the linguistic eloquence of the Bedouin over the city dweller (Bayān, 1: 13, 96-7), noting that 'city eloquence' is learned in any event and lacks the innate accuracy of the Bedouin (ibid., 145) and he specifically notes the corrupting influence of city language (ifs $\bar{a} d$ ), which he admits even affects his own language and the ${ }^{\mathrm{c}}$ Abbāsid scholarly community (ibid., 162-3). 
their book culture were structurally subordinated. Interestingly, al-Bayān wa-l-tabyin is also silent on the translation project undertaken by the ${ }^{\mathrm{c}}$ Abbāsid caliphs, particularly al-Ma ${ }^{\mathrm{m}} \mathrm{u} n$, a figure traditionally considered its prime architect. ${ }^{163}$ Al-Ğāhiz dedicated a book to al$\mathrm{Ma}^{\circ}$ mūn which was apparently well received, ${ }^{164}$ but al-Ğāhịiẓ's writings are devoid of praise for the caliph's interest in foreign books, instead his praise for al-Ma ${ }^{9}$ mūn, is on 'Arabic' grounds - concerning the caliph's eloquence. ${ }^{165}$

Al-Ğāhiz's maintenance of this linguistic underpinning of 'ilm and support for the Arabians led him, somewhat unusually for an ${ }^{\mathrm{c}}$ Abbāsid writer, to express strong admiration for the Umayyads. When al-Ğāhiz enumerates Arab rulers who displayed proficiency in bayan, he emphasises the Umayyads ( $\mathrm{Mu}^{\mathrm{c}} \bar{a} w i y a$, Yazīd, al-Walīd and Sulaymān) as well their Arabian rival, Ibn Zubayr, whereas the ${ }^{\mathrm{c}} \mathrm{Abbāsid}$ caliphs are expressly secondary. ${ }^{166}$ Furthermore, despite the ${ }^{\mathrm{C}}$ Abbāsid interest in book learning, al-Ğāhiz even commends the Umayyads for maintaining the linguistic and cultural traditions of the pre-Islamic Arabians and laments that the ${ }^{\mathrm{C}} \mathrm{Abbāsids} \mathrm{eschewed} \mathrm{what} \mathrm{al-Ğāhiz} \mathrm{considered} \mathrm{the} \mathrm{more}$ virtuous Arabian orality as they turned instead towards the urban writerly culture. ${ }^{167}$ Can this be taken as an indirect slight on the ${ }^{\mathrm{c}}$ Abbāsids for too eagerly adopting the writerly culture and manners of the Persian state secretaries?

Conclusion

Al-Ǧāḥiž's disparate opinions of books, ethnicities and learning merge under the umbrella of his theories about the human intellectual heritage. As a member of the burgeoning writerly culture of Iraq and reader of

163 For example, Ibn al-Nadīm some 125 years after al-Ğāḥiz's death recounts the portentous dream of al-Ma ${ }^{\circ}$ mūn in which the caliph had a vision of Aristotle who urged him to find Greek books for translation (Fihrist, 303-4).

164 Al-Ma ${ }^{\circ}$ ūn's praise for the quality of this book is reported by al-Ğăhiz (Bayān, 3: 374).

165 See Bayān, 1: 91, 115, 3: 374-8. Al-Mamūn's opinions about good books, containing excellent meaning and language together is also cited by alĞāhì, but this concerns his interest primarily in Arabic books. See Rasa $\bar{a}^{\supset} i l, 1$ : 351 (al-Radd ' alā l-Nașarā).

166 Bayān, 1: 383. He expressly notes that the speech of Arab rulers other than the Umayyad era figures mentioned lacked what could be considered proper bayān, thereby placing the ${ }^{\mathrm{c}} \mathrm{Abbāsids}$ in a secondary role. al-Ma ${ }^{\mathrm{D}} \mathrm{m} \overline{\mathrm{n}}$ is mentioned as an outstanding ${ }^{c}$ Abbāsid, however no mention is made of his interest in translating foreign books.

167 Bayān, 3: 366. 
translations from non-Arabic sources, he accepted books as valid transmitters of ${ }^{c} i l m$ and theorised a structure of knowledge transmission via books in which the translation project and the foundations of ${ }^{\mathrm{c}}$ Abbāsid adab culture could be legitimised. So, in al-Hayawān in particular, al-Ğâhiz appears as the bibliophilic humanist and icon of the cosmopolitan book consuming medieval Muslim civilisation. ${ }^{168}$ But this bibliocentric worldview risked an implicit denigration of the bookless Arabians in the ethno-cultural debates of al-Ğăhiz's intellectual milieu. To bolster the status of the Arabians in the story of human intellectual heritage, al-Ğāhiz played to their strengths, and found in his conception of bayān a cogent means to establish the parameters of ${ }^{c} \mathrm{ilm}$ around good language which he argued was the preserve of the Arabians.

In $3 \mathrm{rd} / 9^{\text {th }}$-century Iraq, books by no means dominated the process of knowledge acquisition, and communication retained an oral/aural aspect. This background played into al-Ǧăhiz's hands, permitting him to refrain from unequivocally praising all written texts as authoritative sources of knowledge and to stress the importance of appropriately expressive language in the parameters of the 'praiseworthy book'. While he accepted that some books could be veritable paragons of cultured thought, not all books are equal, and he wielded this re-conceptualised 'ideal book' against the very cultures that based their own superiority on 'book culture'. Construing books in this fashion had another self-serving angle, as his theory implicitly assures that books written in Arabic (such as his own), must be the very best for all time.

Al-Ǧāhiz's dilemma of lauding book culture as legitimator of $a d a b$, and disparaging books to defend the Arabian heritage continued to confront later writers. In the mature writerly culture and on account of their own esteem of books, some would adopt an unambiguously bibliocentric lens to appraise the world, scorning not the non-believing $k \bar{a}$ fir but instead illiterates, and they even laud the polytheistic Babylonians and Pharaonic Egyptians as praiseworthy peoples on account of their perceived book production. But other later scholars would retreat into Arabian particularism, particularly in defence of the Qur ${ }^{\circ} \bar{n}$. Later cosmopolitan bibliophilia would thus continue to be cleft by issues of language and theology. ${ }^{169}$

168 See Enderwitz and Saliba for recent spirited arguments for a synthesising and cosmopolitan al-Ğāhị. Ch. Pellat (The Life and Works, 12) gives more weight to al-Ğạhiz's polemical and pro-Arab, pro-Islam stance, but also indicates that the cosmopolitan spirit of $a d a b$ tempered this to some extent.

169 See Șa $\bar{a}^{\mathrm{c}}$ id al-Andalusī's Ṭabaqāt al-umam for a paradigmatic example of 
Al-Ǧāḥiz was unequivocally a bibliophile, but in his particular Ğāhizian way. I suspect his bibliophilia was at its most effusive when he assessed his own books: while he respected non-Arabic books as sources of knowledge upon which he believed his 3rd/9th-century Muslim civilisation was founded, he probably loved his own writings best. ${ }^{170} \mathrm{Al}-$ Ğāhiz's theoretical framework enabled him to borrow from foreign ' ${ }^{c} i l m$ without having to 'pay' for it by expressing respect for their cultures, since their languages were structurally subordinated. Al-Ğāhiz could thus comfortably extol the virtue of books and write books to his heart's content, confident that he would never have to concede that Aristotle, Bozorgmehr or Ibn al-Muqaffa ${ }^{c}$ could possibly be his equals.

Primary Sources

\section{BIBLIOGRAPHY}

Al-Andalusī, Șā̄id ibn Aḥmad, Ṭabaqāt al-umam, ed. Ḥusayn Munis (Cairo: Dār al-ma'āarif, 1998).

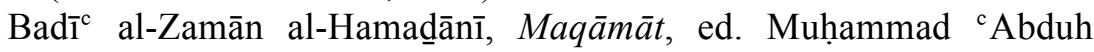
(Beirut: Dar al-mašriq, 1993).

Al-Bāqillān̄i, Muḥammad ibn al-Ṭayyib, $I^{c} \breve{g} \bar{a} z$ al-Qur ān, ed. Aḥmad

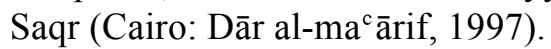

Al-Ğāḥiz, ${ }^{\mathrm{c} A m r}$ ibn Baḥr, al-Bayān wa-l-tabyīn, ed. ${ }^{\mathrm{c}} \mathrm{Abd}$ al-Salām Muḥammad Hārūn, 4 vols. (Cairo: al-Ḩānğ̄î, 1993).

—_, Kitāb al-Hayawān, ed. Muḥammad Bāsil ' ${ }^{c}$ Uyūn al-Sūd 4 vols. (Beirut: Dār al-kutub al-cilmiyya, 1998).

—_, Rasa $\bar{a}^{\supset} i l$, ed. ${ }^{\mathrm{c}} \mathrm{Abd}$ al-Salām Muhammad Hārūn, 4 vols. in 2 (Cairo: al-Hูānğīi, 1964-79).

Al-Halīl ibn Aḥmad, Kitāb al- ${ }^{c} A y n$, eds. Mahdī al-Maḩzūmī and Ibrāhīm al-Sāmarrā̄̄̄̄, 8 vols. (Baghdad: Manšūrāt wizārat al-țaqāfa wa-l- $\left.{ }^{\circ} i^{c} l a ̄ n, 1982\right)$.

an essay where book production and cultural achievement are treated as synonymous in a remarkably cosmopolitan bibliocentric worldview. His support for the merits of Babylonians and Egyptians based on book production is

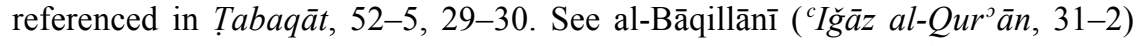
for a foreign book censuring defence of the Arabic language and the Qur ${ }^{\mathrm{a}} \mathrm{a}$.

170 Pellat considered that al-Ğāhiz dispensed with the format of Greek zoological works in al-Hayawān because he was 'convinced that he [had] no need of recourse to Greek ideas, given that all that is found in the zoological works of the 'philosophers' [the Greco-Roman scholars] is known already to the Bedouins.' (Ch. Pellat, 'Hayawān', 312). 
Al-Ḥațīb al-Baghdādī, Tārīh Baġdād, ed. Muștafāa c Abd al-Qādir ${ }^{\mathrm{c}}$ Atā 24 vols. (Beirut: Dār al-kutub al- ${ }^{c}$ ilmiyya, 1997).

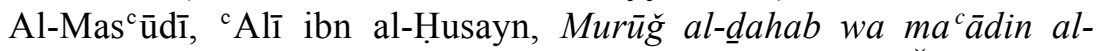
ğawhar, ed. Charles Pellat, 7 vols. (Beirut: al-Ğāmic ${ }^{c} a$ allubnāniyya, 1966-79).

Ibn Manz̄ūr, Lisān al- ${ }^{c}$ Arab, 15 vols. (Beirut: Dār sādir, 1994).

Ibn al-Nadīm, Muḥammad ibn Isḥāq, al-Fihrist, ed. Riḍā Tağaddud (Beirut: Dār al-masīra, 1988).

Ibn Qutayba, Abū Muḥammad ibn Muslim, Fạ̣l al- ${ }^{c}$ Arab wa-l-tanbīh ${ }^{c}$ ala ${ }^{c} u l u \overline{m i h} \bar{a}$, ed. Walīe Hâaliș (Abu Dhabi: Cultural Foundation Publications, 1998).

Al-Ṭabarī, Muḥammad ibn Ğarīr, Tārīh al-rusul wa-l-mulūk, ed. Muhammad Abū Faḍl Ibrāhīm, 11 vols. (Beirut: Rawā̄o ${ }^{\mathfrak{c}}$ al-turāât al${ }^{c}$ arabīi, n.d.).

Yāqūt al-Ḥamawīi, Muğam al-udabāo, 6 vols. (Beirut: Dār al-kutub alcilmiyya, 1991).

Al-Zamaḩšarī, Maḥmūd ibn ' ${ }^{c} U m a r$, Asās al-balāga a (Beirut: Dār șādir, 1992).

Secondary Studies

Abbot, Nabia, 'A Ninth Century Fragment of the 'Thousand Nights': New Light on the Early History of the Arabian Nights', Journal of Near Eastern Studies, 8/3 (1949), 129-64.

Abbot, Nabia, Studies in Arabic Literary Papyri. Vol. 1: Historical Texts (Chicago: Chicago University Press, 1957).

Agha, Saleh Said, 'Language as a Component of Arab Identity in alĞāḥiẓ', in Arnim Heinemann et al (eds.), Al-Ǧāhiz: A Muslim Humanist for our Time (Beirut: Orient-Institut and Ergon Verlag, 2009), 67-90.

Anghelescu, Nadia, Langage et Culture dans la civilisation Arabe, trans. Viorel Visan (Paris: L'Harmattan, 1995).

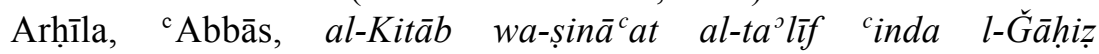
(Marrakech: al-Warrāqa al-wațaniyya, 2004).

Atiyeh, George N., 'Introduction', in G. Atiyeh (ed), The Book in the Islamic World (Albany: State University of New York Press, 1995, xiii-xviii).

Behzadi, Lale, 'Al-Ǧāḥiz and his Successors on Communication and the Levels of Language', in Arnim Heinemann et al (eds.), AlĞähiz: A Muslim Humanist for our Time (Beirut: Orient-Institut and Ergon Verlag, 2009), 125-32. 
Behzadi, Lale, Sprache und Verstehen: al-Gahiz über die Vollkommenheit des Ausdrucks (Wiesbaden: Harrassowitz, 2009).

Bloom, Jonathan M., Paper Before Print (New Haven: Yale, 2001).

Bosworth, C.E., 'The Persian Impact on Arabic Literature', in A.F.L. Beeston et al (eds.) Arabic Literature to the end of the Umayyad Period (Cambridge: Cambridge University Press, 1983), 483-96.

Cook, Michael, 'The Opponents of the Writing of Tradition in Early Islam', Arabica 44 (1997), 437-530.

Dayf, Šawqī. al-Fann wa-l-Mad̄āhibuhu (Cairo: Maktabat al-nahḍa almișriyya, 1946).

Enderwitz, Susanne, 'Culture, History and Religion: À propos the Introduction of the Kitāb al-Hayawān' in Arnim Heinemann et al (eds.), Al-Ğāhiz: A Muslim Humanist for our Time (Beirut: OrientInstitut and Ergon Verlag, 2009), 229-38.

Gériès, Ibrahim, ‘Al-Maḥāsin wa-l-Masāwī’, $E I^{2}$,v, 1223-7.

Ghersetti, A., 'L'utilità della scrittura: testimonianze di alcuni autori arabi medievali', Annali di Ca' Foscari 33 (1994), S.O. 25, 67-76.

Günther, Sebastian, 'Al-Ğāhiz and the Poetics of Teaching', in Arnim Heinemann et al (eds.), Al-Ğăhiz: A Muslim Humanist for our Time (Beirut: Orient-Institut and Ergon Verlag, 2009), 17-26.

, 'Praise to the Book! Al-Ğăhiz and Ibn Qutayba on the Excellence of the Written Word in Medieval Islam', in Franz Rosenthal Memorial Volume, Jerusalem Studies in Arabic and Islam 32 (2006), 125-43.

Lassner, Jacob, The Shaping of Abbāsid Rule (Princeton: Princeton University Press, 1979).

Lecomte, Gérard, Ibn Qutayba (mort en 276/889). L'Homme, son oeuvre, ses idées (Damascus: Institut français de Damas, 1965).

Madigan, Daniel, The Qur ān's Self Image (Princeton: Princeton University Press, 2001).

Montgomery, James, 'Speech and Nature: Jāḥiz, Bayān 2.175-207, Part 3', Middle Eastern Literatures 12 (2009), 107-25.

__, 'Speech and Nature: Jāhiz, Bayān 2.175-207, Part 4', Middle Eastern Literatures 12 (2009), 213-32.

Pedersen, Johannes, The Arabic Book, trans. Geoffrey French (Princeton: Princeton University Press, 1984).

Pellat, Charles, 'al-Djāhị' $E I^{2}$, ii, 385-7.

—, 'Djāhiz et la littérature comparée', Cahiers Algeriens de Littérature Comparée 1 (1966), 95-108.

—_, 'al-Hayawān', $E I^{2}$ iii, 311-13. 
Pellat, Charles, Le Milieu Bașrien et la Formation de Ğāhiz (Paris: Librairie d'Amerique et d'Orient, 1953).

-, 'Nouvel essai d'inventaire de l'oeuvre ğahizienne', Arabica 31 (1984), 117-64.

, The Life and Works of al-Ğăhiz, trans. D.M. Hawke (Berkeley: University of California, 1969).

Rashed, Roshdi, 'Greek into Arabic: Transmission and Translation', in James Montgomery (ed.), Arabic Theology, Arabic Philosophy: From the Many to the One (Leuven: Utigeverij Peeters, 2006).

Rosenthal, Franz, Knowledge Triumphant: the concept of knowledge in medieval Islam (Leiden: Brill, 1970).

Saliba, George, 'Al-Ğāhịiz and the Critique of Aristotelian Science', in Arnim Heinemann et al (eds.), Al-Ğāhiz: A Muslim Humanist for our Time (Beirut: Orient-Institut and Ergon Verlag, 2009), 39-50.

Schoeler, Gregor, The genesis of literature in Islam: from the aural to the read, trans. Shawkat Toorawa (Edinburgh: Edinburgh University Press, 2009).

, The Oral and the Written in Early Islam, trans. Uwe Vagelpohl (London: Routledge, 2006).

—, 'Writing for a Reading Public', in Arnim Heinemann et al (eds.), Al-Ğăhiz: A Muslim Humanist for our Time (Beirut: OrientInstitut and Ergon Verlag, 2009), 51-63.

Toorawa, Shawkat M., Ibn Abì Țāhir Tayfūr and Arabic Writerly Culture (London: RoutledgeCurzon, 2005). 